\title{
O GALEGO-PORTUGUÊS, MATRIZ DO MUNDO LINGÜÍSTICO LUSO-BRASILEIRO*
}

\section{GALICIAN AS THE SOURCE OF THE LUSO-BRAZILIAN LINGUISTIC WORLD}

\author{
Maria do Carmo Henríquez Salido \\ Universidade de Vigo \\ mesalido@uvigo.es
}

${ }^{*}$ ) In memoriam de Joan Coromines, mais umha vez

Resumo: $\mathrm{O}$ período inicial desta breve história da língua galega e o reintegracionismo lingüístico começa com umhas observaçons de umha «Carta» de Martim Sarmiento (I695-I77I), precursor da filologia galega, e finaliza em 20I9, ano em que a Real Academia Galega (RAG), toma o acordo de dedicar-lhe o "Dia das Letras Galegas» ao polígrafo ferrolano Ricardo Carvalho Calero (Ferrol I9Io - Santiago de Compostela 1990). Elaboram-se apenas umhas ideias sobre o século XIX e primeira metade do xx; mais informaçom aparece sobre a segunda metade do século passado e primeiras décadas do xxI.

Palavras-chave: história da língua galego-portuguesa, unidade e diversidade, «orthographia».

Abstract: The initial period of this brief history of Galician and of linguistic reintegrationism starts with some remarks on a «letter» by Martim Sarmiento (1695-177I), the precursor of Galician philology, and ends in 2019, when the Real Academia Galega decides to dedicate the Dia das Letras Galegas (Galician Literature's Day) to the reintegrationist scholar Ricardo Carvalho Calero (I910-1990). Only summarized ideas are here presented on the I9th century and first half of the 2oth century, while more information is given with regard to the second half of last century and the first decades of the 2Ist century.

Key words: history of Galician language, unity and diversity, «orthographia». 
Maria do Carmo Henríquez Salido

O galego-português, matriz do mundo lingüistico luso-brasileiro

\section{PREÂMBULO}

Para nuclear este texto, escolhemos o título da comunicaçom apresentada polo Professor da Universidade Fluminense do Rio de Janeiro, Sílvio Elia (I918-I998), no «I Congresso Internacional da Língua Galego-Portuguesa na Galiza»(Ourense, 1984):

\footnotetext{
Não por outro motivo o consagrado filólogo português Manuel Rodrigues Lapa refere-se a «um galego literário, que é hoje o português falado por I20 milhóes de individuos». (I979: 68)

E dessa alma galega que derramou sobre a Península Ibérica os mais amorosos versos e aliciantes versos da lírica medieval, que povoou de sonhos e proezas a abençoada faixa atlântica do território hispânico, que estruturou em forma harmoniosa e culta um dos idiomas românicos mais pujantes de virtualidades e realizaçóes, que somos os privilegiados continuadores nas terras novas e renovadoras do continente americano. Faz jus, portanto, esse fecundo idioma galego-português ao título de matriz do mundo lingüístico lusobrasileiro. (Elia 1986: 194)
}

Nom deixa de ser surpreendente que um filólogo brasileiro tenha sintetizado com tanta clareza a "história clínica» da língua da Galiza e que o tenha proclamado numha conferência solene; este parecer será compartilhado por outros filólogos brasileiros, portugueses, galegos e europeus nas suas comunicaçons apresentadas nos "Congressos Internacionais [...]», organizados pola "Associaçom Galega da Língua» (AGAL) nos anos 1984, I987, I990 (Homenagem ao Professor Carvalho Calero), I993 (Homenagem a Ferdinand de Saussure) e 1996 (Homenagem a Joan Coromines).

As conferências fôrom publicadas nas correspondentes "Actas» (1987, 1990, I993 e I996). Quanto às do ano I996, realizado em Vigo os dias I3 a I6 de novembro, nom foi possível a sua ediçom, embora o programa fosse excelente, por problemas económicos, dificuldades para reunir os textos e desavenças internas. Centrava-se em quatro grandes blocos temáticos: Ciências da linguagem, Teoria e Crítica Literárias, Estado actual das vertentes do português no mundo e Estudo da obra e dos contributos do Professor Joan Coromines na Lingüística e Filologia Românica e Hispánica (Agália, 47, p. 37I-383).

Elaboramos aqui umha breve história da língua galega (apenas umhas ideias), que estruturamos em três grandes etapas: a) a primeira transcorre desde o século XVIII até finais do XIX com o "Regionalismo» e primeira década do Xx (fundaçom da RAG); b) a segunda desenvolve-se com o "Nacionalismo» desde I9I6 e com um clamoroso e aterrador silêncio, motivado pola situaçom política (I936-I946), em que os nacionalistas vivem exiliados na Argentina e outros países da América; a situaçom muda lentamente a partir do ano I950 e chega até I979, poucos anos depois da morte do ditador; c) a terceira abrange desde I980, um ano depois em que Rodrigues Lapa publica Estudos Galego-Portugueseses (1979), e chega até 2020, um ano depois em que se lhe dedica o «Dia das Letras Galegas» ao Professor Carvalho Calero. As datas, devido ao extenso período cronológico, som aproximadas. 
Maria do Carmo Henríquez Salido

O galego-português, matriz do mundo lingüistico luso-brasileiro

\section{DE SARMIENTO AO «REGIONALISMO»}

I.I Embora existam pareceres discutíveis, o frade beneditino Martim Sarmiento seria o precursor; possui umha clara intuiçom da lingüística românica, um século antes de que F. Diez a constitua como realidade sólida. Crítico e polígrafo extraordinário, da "Carta en respuesta al Rvdmo. P. M. Esteban de Terreros» podemos obter esta informaçom: a) «toda la lengua gallega vulgar y la que consta de los manuscritos antiguos, no es per se, sino una varia inflexión de las voces latinas, es error creerla dialecto de la lengua castellana»; b) «la lengua gallega [...] no sé a punto fijo cuándo se comenzó a escribir; sé sí, que duró el escribirla hasta los tiempos de Carlos Quinto en los instrumentos públicos»; c) «siendo puras raíces latinas las primitivas de la lengua gallega, no se debe extrañar que los gallegos hablen un idioma que parece latín»; (d) «el idioma gallego es el latín estropeado, [...] de las cinco partes de voces gallegas las cuatro son casi voces latinas que significan lo mismo»; e) «el idioma abunda de muchísimas voces radicales y de pocas forasteras [...] siempre exceptúo los gallegos que habitan lugares muy populosos o de comercio. Estos no hablan puro gallego ni puro castellano, sino un tercer idioma champurrado»; f) «Así, la lengua portuguesa pura no es otra que la extensión de la gallega, y que después se cargó de voces forasteras, moriscas, africanas, orientales, brasileñas» [...] «hago tal cual reflexión sobre la lengua gallega que he mamado» (Pensado I974: I8-3I). Sobre a ortografia é da opiniom de que «tem de fundar-se na etimologia [...]: assim utiliza -ss-em posiçom intervocálica [...]; usa três grafemas $g, j$ e $x$ para um mesmo fonema prepalatal surdo ou sibilante [...]. Sobre o uso de $-n$ ou $-m$ registamos umha vacilaçom» (Henríquez I999a: 226).

I.2 No século XIX, o dia 30 de novembro de I833, Javier de Burgos, por decreto, cria as quarenta e nove provincias de Espanha, um ato administrativo do Estado espanhol virá a ser o definidor do "galego», como assevera com certa ironia Carvalho (I983: 29), embora, conforme vemos no mapa da Classificação dos dialectos galego-portugueses (Lindley Cintra 1983: I63), reproduzido por Cunha \& Lindley Cintra (I985: I4-I5), o galego estende-se fora das quatro províncias, chega ao Norte de Portugal e ocupa a faixa ocidental da Península Ibérica (Vid. ANEXO I):

A faixa ocidental da Península Ibérica ocupada pelo galego-português apresenta-nos um conjunto de DIALETOS que, de acordo com certas características diferentes de tipo fonético, podem ser classificados em três grandes grupos: a) DIALETOS GALEGOS; b) DIALETOS PORTUGUESES SETENTRIONAIS; c) DIALETOS PORTUGUESES CENTROMERIDIONAIS.

Caplletra 71 (Tardor, 2021), p. 57-94 


\begin{abstract}
Esta classificação parece ser apoiada pelo sentimento dos falantes comuns do português padrão europeu, isto é, dos que seguem a NORMA ou conjunto dos usos lingüísticos das classes cultas da região Lisboa-Coímbra e que distinguem pela fala um galego, um homem do Norte e um homem do Sul. (Cunha \& Lindley Cintra 1985: I0)
\end{abstract}

Os primeiros indícios no século XIX aparecem em I853. Nesta etapa som evidentes a diversidade de soluçons gráficas, muitas variantes lexicais e morfológicas e a abundância de castelhanismos. A obra A gaita gallega de Pintos (I8II-1876), humanista com formaçom clássica, juiz e fiscal, contém partes em galego e em castelhano; elabora umha apologia geral e reivindicaçom da Galiza e, nomeadamente, da sua língua. Registamos enunciados deste teor: "Ja voan os paxaros», «Si juro", «Das gentes è o consolo», «A saber que se atienda en la escritura / a la etimología del gallego» (p. 70), «Pouco num mesmo parou».

Dos três grandes poetas, Rosalia Castro (I837-I885), Curros Enríquez (I85I-I908) e Pondal (I835-1917), este último será provavelmente a figura mais relevante do reintegracionismo, quer pola prática na escrita («son vagos, sin gente, mouros / só de longe ven ó man»), quer polas afirmaçons que formula das duas culturas (Galiza e Portugal) ou os seus versos «A redenzón da boa nazón de Breogán»). Rosalia Castro nos Cantares gallegos (I863) fai advertências severas contra Castela e proclamas reivindicatórias: "Castellanos de Castilla, I tratade ben ós galego; cando van, van como rosas; cando vén, vén como negros.»; "Probe Galicia, non debes / chamarte nunca española, / que España de ti se olvida / cando eres, jai!, tan hermosa; / Galicia, ti non tes patria, I ti vives no mundo soia, / i a prole fecunda túa / se espalla en errantes hordas».

$\mathrm{Na}$ segunda metade, vem a luz as primeiras gramáticas galegas (Henríquez I986: 443-467; 20I0: 39I-408). A de Mirás (nom se conhece o ano do seu nascimento nem o da sua morte) publica-se em I864; tem um título extenso, que abreviamos, Compendio de gramática gallega-castellana [...], um livro de I47 páginas. Cataloga como idiomas «el vasco, catalán, asturiano y otros» (p. 6) e manifesta que «el proceso de formación de las lenguas es una adulteración del latín» (p. 6). Para denominar o galego utiliza assistematicamente os termos língua, dialecto e idioma: «O conceito de língua vai associado à ideia de degeneraçom [...] $\mathrm{O}$ conceito de idioma fica reduzido às locuçons peculiares, o dialecto, [...] as locuçons e vocábulos privativos [...] se um dialecto se cultiva, se estuda (p. I45), possui umha gramática (p. I45), pode converter-se numha língua» (Henríquez 1987: 452). Toma como paradigma para o galego a ortografia espanhola.

A segunda gramática (1868) é a do sacerdote ourensano Saco (I836-I88I), catedrático de latim e bom conhecedor do grego, um «ensaio de gramática galega», «em 
Maria do Carmo Henríquez Salido

O galego-português, matriz do mundo lingüistico luso-brasileiro

que parte da variedade de língua que se fala, principalmente, na província de Ourense, polos "rústicos"». «Escreve movido polo afám de purificar e dignificar o idioma, [...] umha das tarefas primeiras que tinha toda gramática que procurasse ser normativa»; para este autor a gramática «é umha arte, pois nasce como observaçom, como resultado da "escrupulosa observaçom da linguage falada" " (Henríquez 1987: 453). A parte destinada, sensu stricto à ortografia, é muito breve, ocupa cinco páginas, pois pensa que som aplicáveis à Ortografia do «dialecto galego» as regras da ortografia castelhana (Henríquez 20I0: 407). Entre certas consideraçons citamos:

La lengua gallega, la más dulce y melíflua de cuantas han aparecido en Europa sobre las ruinas del antiguo idioma de Lacio [...] tiempo ha que viene sufriendo una lenta, pero incesante destruccion [...] No puedo menos de deplorar que una de las causas que mas influyen en el hecho que me ocupa, sea el desden, el innoble menosprecio que los mismos hijos del pais arrojan el habla de sus mayores [...] No tiene a menos el valenciano culto servirse del dialecto de su pais para expresarse ante sus compatricios en buena sociedad: ni el andaluz ni el catalan dejan de estimar en mucho sus respectivas lenguas. (Saco I868: vI)

Valadares (I82I-I903) redige Elementos de gramática gallega, preparada para a sua publicaçom em I892, que nom será editada até oitenta anos mais tarde (I970). A diferença dos outros gramáticos, manifesta interesse polos problemas ortográficos e formula os três princípios que ham de reger a escrita correta do galego: a clareza, a grafia etimológica para harmonizar com outros países do Sul da Europa e prestigiar ou nom desluzir a escrita. Ante a intensa polémica e o debate existente a respeito do uso de determinadas grafias e sobre "o modo de escribir en gallego» pontualiza:

Y aquí entra la gran cuestión sobre el modo de escribir en gallego dichas dos sílabas, si se han de escribir con $g$, con $j$, o con $x$, cuestión en la cual la diversidad de pareceres nace en parte, [...] del cariño que, en fuerza de su uso han tomado, unos a la $x$; otros, á la $g$ y $j[\ldots]$ Letra revoltosa esta última, vieja metida a joven, cuenta, sin embargo, numerosos partidarios y es la que más divide á los que escribimos en gallego. Nosotros [...] escribimos y escribiremos, no $x e, x i$, sino, ge, gi en las voces que así se escriban en castellano. [...] Sí, pues el latino escribe v.g. justitia, el castellano justicia, el portugués justiza, el francés y el inglés justice y el italiano giustitia, pronunciando cada uno esta palabra según su lengua, ¿por qué lo hemos de hacer con $x$ los gallegos y no procurar la uniformidad en la escritura de los vocablos? (Valadares 1970: 19-20)

O 24 de junho de 1894 nos "Jogos florais de Tui», Murguia (I833-I923) proclama que o galego foi feito, no outro lado do Minho, polos irmaos portugueses um idioma universal e por isso assevera: «nunca pagaremos aos nossos irmaos de Portugal [...] que tenham feito do nosso galego um idioma universal». No ano 1906 terá lugar a fundaçom da $R A G$, e o seu primeiro presidente será Manuel Murguía. 
Maria do Carmo Henríquez Salido

O galego-português, matriz do mundo lingüistico luso-brasileiro

2. O "NACIONALISMO» (1916-1936), O LONGO E ESTREMECEDOR SILÊNCIO (1936-1946) E O TÍMIDO ALVOR DA LÍNGUA E DA LITERATURA (1946-1979)

No ano 19I6, a Galiza passa do regionalismo ao nacionalismo, e os movimentos reintegracionistas avançam por motivo do trabalho desenvolvido polas «Irmandades de Amigos da Fala", os representantes da "Geraçom Nós» e até pola força que tem no ideário do «Partido Galeguista» (fundado o 6 de dezembro de 1931). Nom há que silenciar que o Is de setembro de 1923 o rei nomeia chefe do governo o General Primo de Rivera (I923-I93I), iniciando-se assi o diretório militar (I5-X-I923 até 3-XII-I925), o ditador apoia-se no exército como peça de mudança do sistema político. A repressom e censura chegam até por volta de 1935 .

2.I A primeira «Irmandade da Fala» funda-se na Corunha o i8 de maio de i9ı6, nesse mesmo ano publica-se o primeiro número do Boletim Dezenal A Nosa Terra. As «Irmandades» som um movimento político nacionalista, que tem como "finalidade essencial o enobrecimento, a exaltaçom, a dignificaçom e o fomento do idioma, combinado com todo um projecto de regeneraçom do País»; defendem a unidade com a língua falada em Portugal e o binómio língua-naçom. Está constituído por um grupo de intelectuais, sem específica formaçom filológica ou lingüística, pertencentes à burguesia, que «entendem que a reabilitaçom da sua língua está no uso, preocupados pola "gramática” e pola "ortografia”, de preferência etimologizante» (Henríquez 1997: 373).

Podemos distinguir três épocas: a primeira 1916/1918, de definiçom ideológica, a segunda desde I9I8 a fevereiro de 1922 e a terceira a partir de fevereiro de $1922 \mathrm{com}$ umha cisom em dous grupos. Na nossa opiniom, a etapa I9I6-I920 é o momento mais brilhante: «Se os anos I9I6-I9I7 som os anos da defesa do idioma por ser um factor fundamental para a existência de umha naçom, o ano I9I8 vai ser o ano da defesa da ortografia "histórica" ou "etimológica" " e o ano I9I9 o ano da "polémica ortográfica»; «recebem a sua formaçom científica a través de fontes indirectas (da Catalunha), ou exprimido com outras palavras, "lem" através de Catalunha (naçom que citam como modélica no uso da sua língua própria» (Henríquez 1993: 177). A revista deixa de publicar-se em 1936.

Outro contributo das «Irmandades» será o Vocabulario Castellano-Gallego, editado na Corunha em I933; o seu autor foi Salvador Mosteiro Pena (I896-I982). Sustenta: «después de consultar [...] nuestros escritos [...] de los siglos XIII, XIV, XV y xvi y de esculcar [...] el lenguaje hablado en la actualidad [...] llegamos al pleno 
Maria do Carmo Henríquez Salido

O galego-português, matriz do mundo lingüistico luso-brasileiro

convencimiento [...] de que no existe término netamente portugués que no sea gallego, y viceversa» (I933: 4-5). No tocante à ortografia mostra-se partidário de tomar «O exemplo dos escritores da segunda metade do século XIX [...]; nos termos científicos ou técnicos, que coincidam ou quase coincidam com os das outras línguas latinas, respeitam a etimologia» e entende "que há que chegar a umha unificaçom o mais completa possível [...] até, mesmo, identificá-la com a portuguesa na maioria dos casos, por tratar-se de umha mesma língua» (Henríquez i999b: 226-227).

Os problemas que levanta a formalizaçom gráfica dos idiomas ocupa bastantes páginas do Boletim. Conheciam «a problemática existente em Euskal Herria e Catalunha, pois [...] mencionam o «Institut d'Estudis Cataláns» e a futura criaçom do «Instituto de Estudos Vascos», sabiam dos seus trabalhos "para unificar a língua e intensificar a cultura própria» (Henríquez 1993: 192). O debate ortográfico intensifica-se no ano I919, com vozes a favor da escrita "fonética» e da "etimológica». Com a chegada do ano I920, observa-se certo declínio do Boletim.

Acaso os seus mais significados representantes sejam Vilar Ponte (I88I-I936), seguidor de Murguia, por ter realizado umha intensa atividade para consolidar esta nova organizaçom. Reitera «um discurso tardo-secular iniciado já com L. Hervás y Panduro e formulado por Herder e W. von Humboldt, considera a língua como o factor essencial para a existência de umha naçom» (Henríquez I993: I80). Outra figura importante é Viqueira (I886-I924), que, licenciado em Filosofia e Letras em I9II, se doutora em Madrid em I9I3, sendo fervente defensor de incorporar o galego ao ensino. Com rotunda e absoluta clareza justifica o uso da ortografia etimológica:

\footnotetext{
A ortografía que emprego nos meus traballos admitina - respetando inmensamente ôs que non a usan- pol-os seguintes motivos: a) é a antiga ortografía galega; b) somella moitísimo â portuguesa e facilita pois o aumento de leitores, c) coincide c'as das outras línguas latinas, d) é etimológica, e) foi defendida e empregada nas suas publicacións por Antonio de la Iglesia no século XIX, $\mathrm{f}$ ) pode ser base da fonética galega hoje tan castelanizada. (A Nosa Terra, 30 de agosto de 1917)
}

2.2 Da «Geraçom Nós» consideramos de enorme relevância a elaboraçom e promoçom da revista Nós, Boletim mensal de Cultura galega, nascida o 30 de outubro de 1920; os derradeiros números (I39-I44) desta época fôrom impressos como correspondentes a julho-dezembro de 1935 . Os fundadores do citado Boletim fôrom Vicente Risco (I884-I963) e Arturo Noguerol (I880?-I936). Estivo interrompida entre o número I8 (julho de 1923) até julho de 1925, por motivos económicos, políticos e polas desavenças internas. Os seus objetivos serám substancialmente dous: «a) [...] mostrar que a Galiza existia como povo diferenciado enquanto fosse capaz [...] de

Caplletra 71 (Tardor, 2021), p. 57-94 
criar e conservar umha cultura própria, o que significa ser povo; b) [...] superar o isolamento aldeao da Galiza literária através da europeizaçom da sua cultura» (Henríquez 1989: 26I). A maioria dos seus integrantes defendem a escrita histórica ou etimológica.

A repercussom do movimento reintegracionista na política é evidente num folheto publicado polo "Partido Galeguista» (novembro de I934), onde se afirma "que o galego se pareça ao português nom tem nada de particular, porque o português nom é mais que o galego um pouco modificado; de maneira que se tem que parecer por força, e nom é estranho que se pareça» (Henríquez 1984: 27).

A partir de 1940, polo drama da guerra 1936-1939, umha grande parte do trabalho dos nacionalistas galegos realiza-se em países da América. Castelao (I886-I950) reside algum tempo em Nova Iorque, onde tinha sido enviado polo governo republicano para apoiar os exiliados, e nomeadamente na Argentina. Em Buenos Aires publica Sempre en Galiza (1944); Castelao «foi um importante político nacionalista republicano e ideólogo do nacionalismo galego do século xx» (Coromines). Neste livro nom achamos umha praxe ortográfica que demonstre os seus postulados da unidade lingüística galego-portuguesa, mas sim o verificamos no léxico e nas suas ideias: «Estamos fartos de saber que o povo galego fala un idioma de seu, fillo do latín, irmán do castelán e pai do portugués [...] co que ainda podemos comunicarnos con mais de sesenta millóns de almas» (Henríquez i999a: 227). Vam ser parte das obras citadas com anterioridade os principais documentos que utilizará Joan Coromines no $D C E C H$ (1980-I99I):

\footnotetext{
dicionários da língua galego-portuguesa, gramáticas, vocabulários, glossários e léxicos, obras importantes da época medieval e umha escolma da obra de um escritor que foi ademais um importante político nacionalista republicano e ideólogo do nacionalismo galego do século xx -Alfonso Daniel Rodríguez Castelao - como podemos ler e observar no apartado intitulado «Indicaciones bibliográficas». (DECCH, I, XXXVII-LXv) (Henríquez I999a: 223)
}

2.3 No ano I950 inicia-se um tímido ressurgir da literatura e cultura galega; funda-se a editora Galaxia. Guerra da Cal (I9II-I994), exiliado nos Estados Unidos, reinicia esse trabalho de integraçom nos seus dous livros de poesia, Lua de além mar (1959), prefaciado por Jacinto do Prado Coelho, e Rio de Sonho e Tempo (1963).

Em 1963 nasce a revista Grial (Vigo) — de caráter trimestral, constituída em ponto de referência para obter informaçom sobre a cultura e a língua da Galiza-; o número I corresponde a julho, agosto e setembro. Um dos grandes méritos desta revista para o filólogo português Rodrigues Lapa «é o de, por máo hábil dos seus directores (honra lhes seja), abarcar num mesmo complexo os três ramos da nossa cultura: o galego, o português e o brasileiro» (Rodrigues Lapa 1979: 53). 
No jornal Faro de Vigo (I4-X-1964) [em dezembro desse mesmo ano o novo diretor será Álvaro Cunqueiro Mora (I9II-198I); exerceu como jornalista durante toda a sua vida; poeta e narrador em galego], numha entrevista ao Professor Ricardo Carvalho Calero, perante a pergunta "¿Qué es el idioma para Galicia?», ele responde, entre outras ideias, que «Recientemente se ha hablado del gran porvenir del romance gallego-portugués, con sus dialectos. Ahora mismo lo hablan muchos millones de hombres»:

Es la sangre que vivifica el cuerpo espiritual del país. Renunciar a él sería renunciar a ser lo que somos. Y eso jamás se puede hacer, en nombre de ninguna conveniencia, en nombre de ningún principio. Puesto que tenemos un idioma propio, sólo un enajenado puede pensar seriamente que semejante don divino debe menospreciarse [...] Juzgo alienación toda postura que desdeñe el idioma porque creo que tal posición sería extraordinariamente opuesta a nuestros intereses prácticos. Recientemente se ha hablado del gran porvenir del romance gallego-portugués, con sus dialectos. Ahora mismo lo hablan muchos millones de hombres. Pero aun no siendo así, un idioma propio es un certificado de identidad que permite a su poseedor desenvolverse en la vida sobre una base firme. Por otra parte, ese idioma se ha realizado en una literatura brillante. ¿Quién renunciaría a conocerla y a continuarla? -¿cómo hacerlo si no se conoce y se cultiva el idioma?

2.4 Rodrigues Lapa (I897-I989), em Grial, 4I, p. 278-287, publica «A recuperação literária do galego», publicado anteriormente em Colóquio / Letras, I3 (1973), p. 5-I4. Este texto motivou um forte e esclarecedor debate na Galiza, com ensaístas que mostravam o seu otimismo pola «expansión crecente da língua galega», como Ramón Piñeiro (1915-I990), [um dos defensores do «galego champurrado» ou «castrapo», promotor também do debilitamento ou desaparecimento do histórico "Partido Galeguista», integrou-se no PSOE). Em Colóquio / Letras, 8, p. 53, publicava um relatório «sobre a expansión crecente da lingua galega»; apoiava-se o em cinco razons: a transigência da Igreja; Universidade por ter criado umha cadeira de Lingüística e Literatura Galega e um e um Departamento de Filologia Românica; a própria Academia Galega que tinha elaborado jás as «Normas ortográficas e morfolóxicas» do idioma; e, enfim, notava-se a penetraçom do vernáculo em certos meios da burguesia urbana, que «tradicionalmente viña sendo o principal enemigo interior do seu desenvolvimento». Entre os contrários a esse otimismo, citamos o artigo de Coromines e dous trabalhos de Montero Santalha "Unificación ortográfica galego-portuguesa», Grial, 5I, p. I-I3, e «Sobre a unificación ortográfica galego-portuguesa», Grial, 53, p. 277-282, nos quais popom modificar a ortografia comum galega, tomada do castelhano, para unificá-la progressivamente com a luso-brasileira adotando as grafias «lh», «nh», «-m», «Ç», «SS» $[. .$.$] .$ 
Joan Coromines (1905-1997), em Grial, 53, p. 277-282, publica «Sobre a unificación ortográfica galego-portuguesa» (Vid. ANEXO II), em que após felicitar efusivamente filólogos e escritores galegos e concordar com eles, toma partido a respeito de qual devia ser o rumo a seguir polo galego-português, para que nom fosse devorado polo castelhano; pom ênfase em que o principal adianto a fazer na direçom da unificaçom lingüística galego-portuguesa é no campo da unidade ortográfica:

Quen isto escrebe é un lingüista estranxeiro, mas sinceramente cheo de boa vontade para todas as línguas hispánicas, fondamente entusiasta e preocupado das cousas da Galiza. Catalán. Autor do Diccionario Crítico Etimológico de la Lengua Castellana e de moitas obras de lingüística romance. Non son un principiante nos traballos de filoloxía galega [...]. Por outra parte, os meus deberes están do lado do catalán, a única língua miña. O castelán e o galego-portugués son idiomas irmáns, que teño estudado profundamente, para o galego-português a miña profunda simpatía, para o castelán a desconfianza que merece unha língua que pretende devorar ás outras.

A seguir elabora umhas propostas que subdivide em três apartados: (a) Problemas meramente gráficos (LH, NH, emprego do trazo de unión, acentos); (b) Problemas de natureza gráfico-fonética (uso de G, J, X, C, Ç, Z; SS; grupo QU; sobre a nasalidade salienta que «é este o ponto en que sería máis difícil chegar á identidade completa con o portugués», recomenda provisoriamente a adopçom de -M final em lugar de $-\mathrm{N}$, aduzindo como razom fundamental que os portugueses escreverom -om,-am até o século passado [...]. Foi nomeado «Membro de Honra» da AGAL em fevereiro de 1985 e numha carta, que nos remete desde Pineda o 2I de fevereiro de 1985, responde: «Aceito com prazer a vossa honra. / Viva Galiza. Joan Coromines» (reproduzida em Agália, 48, p. 426).

Desde Portugal, Rodrigues Lapa (1979) proclama no «Prefácio» do seu livro Estudos galego-portugueses, que colige trabalhos dispersos, considera a Galiza «como a sua própria terra; e historicamente e geograficamente assim é, pois estou dentro dos limites da velha Galécia» e afirma que se sente vinculado a ela "pelo coração, que apoia naturalmente todos os que defendem a sua liberdade e a sua cultura»:

Estão coligidos neste volume [...] os trabalhos dispersos sobre o problema do galego, que assinalaram a minha actividade ao longo de mais de quarenta e sete anos. [...] Sempre considerei a Galiza, esta terra maravilhosa, desgraçada e incompreendida, como sendo a minha própria terra; e historicamente e geograficamente assim é, pois estou dentro dos limites da velha Galécia, que chegava pelo sul ao rio Mondego. Mas também lhe estou vinculado pelo coração, que apoia naturalmente todos os que defendem a sua liberdade e a sua cultura. (Rodrigues Lapa 1979: I)

Acrescenta que nom comparte a parecer de Ramón Pińeiro — conhecido na Galiza pola sua defesa do galego-espanhol e nom do galego-português-, lembra-lhe: «Sejamos francos e sinceros e náo nos iludamos: utilizando uma expressão do nosso 
Eça de Queiróz (I849-1900), o Governo tolera, mas não promove» (Rodrigues Lapa 1979: 55) e formula umhas argumentaçons, para a construçom dessa koiné tam desejada; concretiza as primeiras operaçons a fazer «a sua descastelhanização, limpando-o de formas que desnaturam a sua verdadeira fisonomia», para restaurar o galego «obrigá-lo a ser o que já foi, um instrumento artístico que as desvastaçóes do tempo, a maldade e a incúria dos homens foram deteriorando», "mas nem por isso deixou de ser radicalmente a mesma língua»:

[...] julgamos que a primeira operação a fazer no idioma é a sua descastelhanização, limpando-o de formas que desnaturam a sua verdadeira fisonomia [...]. Também urge outra operação, mas já em sentido diferente: aproximá-lo de certas formas cultas, idênticas em português e castelhano, e que no galego conservam ainda uma configuração inaceitável e antiliterária: pra em vez de para, terreo em lugar de terreno [...]. Há pois que restaurar o galego e obrigá-lo a ser o que já foi: um instrumento artístico que as devastaçóes do tempo, a maldade e a incúria dos homens foram deteriorando e desfigurando, até ficar no estado em que o vemos. Totalmente identificado nos séculos XII e XIII com o português, separou-se deste por razóes conhecidas, mas nem por isso deixou de ser radicalmente a mesma língua. (Íbid: 62-63)

\section{DE 1980 A 2020: O REINTEGRACIONISMO REGRESSA ÀS SUAS ORIGENS}

3.I A publicaçom das Normas ortográficas do idioma galego, elaboradas por umha Comissom Lingüística, constituída, entre outros, por Ricardo Carvalho Calero (presidente), Ramom Martínez López (Vice-Presidente) e José Luís Rodríguez Fernández (Secretário), representou umha forte aposta no processo de normativizaçom. No «Limiar» avisam: o sistema ortográfico nom pode manter-se indefinidamente inalterado, máxime tratando-se de umha língua, como o galego, na qual o processo de normalizaçom é particularmente laborioso e delicado; por isso prevemos umha futura reorganizaçom da ortografia do idioma, fundada na tradiçom literária [...] mais solidária de outras formas do romance hispânico ao que pertence o galego.

O dia 2 de outubro de I98I é legalizada polo «Ministerio del Interior» a Associaçom Galega da Língua (AGAL), para conseguir «umha substancial reintegraçom idiomática e cultural do galego, nomeadamente nas suas manifestaçons escritas, na área lingüística e cultural que lhe é própria a galego-luso-africano-brasileira». No ano 1982 inicia um intenso trabalho (cinco congressos internacionais, seminários, cursos, colóquios, simpósios, etc.; o número I da revista Agália aparece em março de 1985.

Em 1982 publicam-se as Normas ortográficas e morfolóxicas do idioma galego, aparecem como um acordo da RAG e do Instituto da Lingua Galega (ILG). Nom obstante, estas Normas reduzem-se às do ILG, alteradas em poucos casos; fôrom excluídos os

Caplletra 71 (Tardor, 2021), p. 57-94 
membros da Academia herdeiros da tradiçom e do ideário lingüístico e ortográfico; no fundo nom som mais que umha "contestaçom» às teses reintegracionistas».

Em 1983, a Comissom Lingüística (CL) da AGAL apresenta o Estudo crítico [...] segunda ediçom corrigida e acrescentada em 1989 (302 p.). Descreve a situaçom da comunidade lingüística nos últimos tempos (desde I950 até I975; desde 1976 até I98I; desde 198I até I983, depois do "golpe de estado»), e a situaçom depois da publicaçom do Estudo crítico (indica as açons institucionais e acontecimentos societários em p. I8-24). A seguir elabora um estudo detalhado sobre os princípios e as exigências das Normas ILG-RAG e leva a cabo a crítica pontual (p. 57-I48); no Posfácio pontualiza: "Umhas normas de recta escrita devem ser concisas, bem fundadas, coerentes e razoáveis»; "A espanholizaçom que aceitam as Normas é gratuíta e dupla para a maior parte dos casos: primeiro, contra a nossa tradiçom e, segundo, contra a pertença à nossa própria área cultural e lingüistica (a galego-luso-africano-brasileira»; "É possível chegar a umha normativa de concórdia se se começa, como mínimo, a dialogar sobre as possibilidades de alcançá-la» (p. I49-I54). Recolhe muitas das unidades lexicais "proibidas polas Normas ILG-RAG» ou nom recomendadas, documentadas nos grandes escritores do século XIX, intelectuais das "Irmandades da Fala» e da "Geraçom Nós» (por ex. agravo, até em vez de ata, bloco [Bloco Nacionalista Galego] em vez de bloque, borboleta, carregar, concelho 'divisom administrativa' e Câmara Municipal 'local onde som realizadas reunions ou atividades deliberativas', direito, eixo, fechar, Galiza, gostar, janela, Natal, obrigado 'ficar agradecido', perto 'próximo', preto 'como sinónimo de negro', respeitar...

Nesse mesmo ano, a "Xunta de Galicia», como fruto do afám «normalizador» promulga a Lei 3/1983 de Normalización Lingüística de I5 de junho (DOG de I4 de julho de I983), e o Decreto I35/ I983, de 8 de setembro (DOG do I7) «polo que se desenvolve para o ensino» esta Lei e o Decreto I73/1982, de I7 de novembro (DOG de 20 de abril de 1983) «sobre normativización da Lingua Galega». Todos estes textos legais significam a obtençom das licenças oficiais para fazer com maior honra o «funeral do galego» e laminar qualquer crítica, debate ou diálogo sobre o precitado Decreto.

$\mathrm{O}$ «mestre da nova Galeguidade», Guerra da Cal, manifesta-se, poucos anos depois, sobre o conflito existente na Galiza, identifica os «dois bandos que degladiam», um o poder autonómico "com todos os seus recursos, o seu nepotismo» e o outro «a mocidade universitária e trabalhadora que quer uma Galiza galega, descansa na progressiva adopção do padrão luso-brasileiro que os "reintegracionistas" perfilham»:

O momento actual é de conflito [...]. Dois bandos se degladiam diariamente: num alinham os que neste momento detêm o poder autonómico — clientes e agentes do Estado Central, com todos os seus recursos, o seu nepotismo e os seus meios de comunicaçáo de massas na mão [...]. Esse é o bando da "Xunta de Galicia» [sic], que, de colaboração com algumas entidades «isolacionistas» esclerosadas, engenhou e «oficializou», de maneira maleficamente subreptícia, 
umas aberrantes Normas cujo evidente propósito é condenar o galego ao languidescimento como dialecto — do espanhol [...]. Do outro lado, contra essa armadilha da colonização de novo estilo, levanta-se em onda cada vez mais alta mocidade universitária e trabalhadora que quer uma Galiza galega. À cabeça dessa juventude militam os «reintegracionistas», em cujo triunfo final tenho uma fé inabalável — até por razóes biológicas [...]. Ora bem, eu tenho a convicçáo de que a única defesa do galego contra a política linguicida dos «espanholizantes» descansa na progressiva adopção do padrão luso-brasileiro que os «reintegracionistas» perfilham. (Guerra da Cal I985: IO-II)

Embora seja um facto conhecido polos leitores da língua românica que ocupa a faixa oriental da Península Ibérica, reproduzimos a seguir umha referência à problemática catalá que apresenta certo paralelismo com o que temos descrito nas primeiras páginas deste artigo: «Que magistrats nomenats per l'Estat provin d'introduir una divisió en la unitat de la llengua literária i oficial catalana, preceptuant l'ús d'ensenyaments i textos en «llengua valenciana i no catalana»:

Em junho de 1989 o "Ministerio de Cultura» concedeu o "Premio Nacional de las Letras» ao Professor Joan Coromines. Este numha carta dirigida ao Sr. Jorge Semprún, dá-lhe as graças, e dize: [...] D'altra banda, no puc deixar de dir-li, que la satisfacció que aqueixa distinció em dóna, va acompanyada d'una profunda recança. L'única nació, i l'única llengua meva, a les quals reto incondicional homenatge, són la nació i la llengua catalanes [...]. Considero intolerables alguns fets. Primer, que s'admetin en els Països Catalans, mestres agents de policia i altres funcionaris sense haver acomplert coneixement de la nostra llengua. Segon. Que es regategi, o sotmeti a hàbils maniobres, el suport incondicional a l'oficialitat del català en el si de la Comunitat Europea, i del seus programes d'ensenyament lingüístic. Tercer. Que magistrats nomenats per l'Estat provin d'introduir una divisió en la unitat de la llengua literària i oficial catalana, preceptuant l'ús d'ensenyaments i textos en «llengua valenciana i no catalana». (Agália, I8, p. 259)

3.2 A realizaçom dos cinco «Congressos Internacionais [...]» representa um reconhecimento internacional da unidade da língua galego-portuguesa. No I Congresso Internacional [...] (Ourense, 1984), Rodrigues Lapa estuda a figura de Álvaro de las Casas (I9OI-I950), diz que este escritor preferia que o chamassem Álvaro das Casas, por ser a forma correta em galego. Considera-o umha figura esquecida na história literária da Galiza, que aconselhava «sujeitar-se à ortografia lusitana», pois «cientificamente, este é o nosso caminho, e política e economicamente os nossos eidos estender-se-iam num dos mais vastos mundos lingüísticos»:

Cuido que deveríamos sujeitar-nos no possível ao português, tanto mais que, na maior parte dos casos ficávamos mais dentro das nossas formas originárias: Deus por Dios, mai por nai, perto (cerca) por preto (que tem outra significação = negro); sinos por campás; xanela por ventá ou fiestra. É melhor que nos sujeitássemos à ortografia lusitana. Cientificamente, este é o nosso caminho; e política e economicamente os nossos eidos estender-se-iam num dos mais vastos mundos linguísticos (Alento, 5, p. 87-88) (Rodrigues Lapa 1986: 268). 
Nas «Conclusons» deste «I Congresso [...]» aparecemr:

I. O Congresso reafirma que as duas formas do galego e do português constituem um mesmo sistema lingüístico, umha mesma língua. 2. O Congresso reafirma também que a norma que corresponde ao galego tem de ser fixada com critérios lingüísticos e um necessário debate democrático aberto a todos os especialistas e sectores implicados. 3. O Congresso apoia todos os processos conducentes à plena normalizaçom lingüística do galego que deverá afectar com carácter prioritário ao ensino, meios de comunicaçom e administraçom. 4. Os congresistas dos países de língua galego-portuguesa urgem a necessidade de reforçar e multiplicar os intercámbios culturais e troca de experiências no interior desta comunidade lingüística [...] (Actas I986: 8I4-8I5)

No «II Congresso [...]» (1987), Chaves de Melo (I917-200I) justifica o título da sua dissertaçom, pois trata do galego como parte integrante do sistema hoje denominado «língua portuguesa», e confessa que vinha de longe «o meu interesse pelo galego» (p. 59), aconselha «as formas coincidentes com o luso brasileiro, para abreviar o desejado termo da perfeita reintegração» e convida a que "nos irmanemos galegos, portugueses e brasileiros e proclamemos "A nossa pátria é a língua portuguesa”»:

Um apelo aos que estão trabalhando na ingente e histórica empresa da gramaticalização e disciplinação do galego comum, para que prossigam e tomem nota como norte, nos casos de divergência acidental, o aconselhamento das formas coincidentes com o luso-brasileiro, para abreviar o desejado termo da perfeita reintegração. É um convite a que, de alma leve, nos irmanemos galegos, portugueses e brasileiros e proclamemos "A nossa pátria é a língua portuguesa». (Chaves de Melo i990: 66-67)

Carvalho Calero assinala que «devemos interpretar o reintegracionismo de Castelao [...] no contexto temporal em que publica a sua obra»; «tanto o seu bilingüismo como o seu reintegracionismo som posturas políticas»; «o galego incorporaria-se ao sistema de que foi protótipo e que hoje tem como arquétipo a norma lisboeta, sem deixar de ser galego»; esse achegamento ao português «ha desembocar em confusom, quer dizer, em confluência, que nom é seguramente substituiçom, senom osmose»:

Cabem muitas possibilidades interpretativas da fórmula; mas eu creio que a mais correcta em virtude do contexto histórico é a mais puramente «reintegracionista»: o galego incorporaria-se ao sistema de que foi protótipo e que hoje tem como arquétipo a norma lisboeta, sem deixar de ser galego, conservando a sua fonética, a sua morfologia e o seu léxico peculiares no que tenhem de genuínos, mesmo aportando ao sistema o que puder enriquecê-lo e, decerto, admitindo todo o que, proveniente das outras formas do galego-português, resultasse rendível para o co-dialecto [...] Castelao nom nos hipoteca o porvir. Limitou-se a indicar um caminho para o futuro inmediato ao presente de 1944, que em grande parte é o futuro inmediato no presente de 1987. (Carvalho I990: 900)

Eugenio Coseriu (I92I-2002) reafirma estes princípios: «es el portugués el que es "gallego" ", "históricamente es el gallego de la Reconquista y es hasta hoy, en todas 
sus formas, la continuación de ese gallego». Se trata "de una lengua, que precisamente en la forma en que se difunde [...] se llama con otro nombre» (Vid. ANEXO III):

Claro que esto no significa que el gallego sea "portugués»; significa más bien lo contrario: es el portugués el que es "gallego». Históricamente, el portugués es el gallego de la Reconquista y es hasta hoy, en todas sus formas, la continuación de ese gallego. Esto vale también para el portugués literario y común en su relación con el gallego literario medieval, pues la tradición de este gallego ha sido adoptada y continuada por la lengua literaria portuguesa. Se trata, por tanto, del caso, bastante raro en la historia de las lenguas, de una lengua que, precisamente en la forma que se difunde y se constituye en lengua común y gran lengua de cultura, se llama con otro nombre: ya no gallego, sino portugués. (Coseriu I990: 800)

Azevedo Filho (I927-20II) constata que «há sempre duas forças em permenente tensão, a força agregadora que mantém a unidade da língua, e a força desagregadora, responsável por sua desarticulação», e considera que «a força desagregadora, responsável pela expansão do castrapo, decorre do conjunto de inevitáveis influências da língua castelhana [...] sobre a língua de Martin Codax e Pero Meogo», mas parece «não haver dúvida de que o reintegracionismo será sempre a luta por um ideal, em face de uma realidade cada vez mais adversa»:

Em suma, no interior de qualquer sistema lingüístico, há sempre duas forças em permanente tensão: a força agregadora, que mantém a unidade da língua, e a força desagregadora, responsável por sua desarticulaçáo. No caso do galego, a força agregadora é a mesma que dá unidade ao português hoje falado em sete naçóes. E a força desagregadora, responsável pela expansão do castrapo, decorre do conjunto de inevitáveis influências da língua castelhana, ao longo da história, sobre a língua de Martin Codax e Pero Meogo [...] parece não haver dúvida de que o reintegracionismo será sempre a luta por um ideal, em face de uma realidade cada vez mais adversa. (Azevedo Filho 1993: 82)

No «III Congresso [...]», celebrado em I990, Eugenio Coseriu consolida novamente a unidade, pois «uma semântica estrutural do galego e do português chegaria à conclusão de que o sistema básico é o mesmo no galego e no português [...]», «as distinçôes, as oposições básicas, os traços diferenciadores são os mesmos»:

Um estudo deste tipo, uma semântica estrutural do galego e do português chegaria à conclusão de que o sistema básico é o mesmo no galego e no português e de que as distinções, as oposições básicas, os traços diferenciadores são os mesmos, mas que há [...] diferença de norma, como há também diferença de norma entre o português de Portugal e o português do Brasil e também no português das várias regiốes de Portugal e no português das várias regiôes do Brasil. (Coseriu I993: IOO)

Os professores brasileiros presentes neste «III Congresso [...]» propugerom um voto de louvor aos organizadores do Encontro, pelo: 


\begin{abstract}
Rigor e eficiência, pela constante gentileza no trato, pela qualidade das Comunicações, pelo enriquecimento e progresso na abordagem dos temas examinados. Propóem igualmente, que esta moção seja dirigida na pessoa da Profa ${ }^{\text {. Dra }}$. Maria do Carmo Henríquez Salido, alma da Associaçom Galega da Língua, incansável batalhadora da causa da Reintegração e líder incontestável de quantos se empenharam a fundo para levar a bom termo a sua luta. Ourense, I de outubro de 1990 .

Assinam este documento: Gladstone Chaves de Melo, Sílvio Elia, Leodegário A. de Azevedo Filho, Dalma B. Portugal de Nascimento, Maria Amparo Tabares e Maria Alice Aguiar. (Actas do III Congresso, 1993: 638)
\end{abstract}

A abertura do «V Congresso [...]» tivo lugar o dia 13 de novembro de 1996 no auditório do Centro Cultural Caixavigo; a mesa estivo presidida polos Professores Azevedo Filho, Eugenio Coseriu, Hans J. Niederehe e Maria do Carmo Henríquez. Referenciamos, apenas, os títulos e autores das conferências plenárias e das que abordam a obra de Joan Coromines ou o catalám. Às I6:20 h. Eugenio Coseriu (Univ. Tübingen) «A norma e o ensino das línguas». Às 18:0o h. Hans J. Niederehe (Univ. Trier) «Los catalanes y la gramaticografía de la Edad Media».

O dia I4, Evanildo Bechara (Univ. do Estado Rio de Janeiro) «Os estudos de etimologia portuguesa e a obra de Joan Corominas». O dia I5, José Luís Álvarez Enparantza (Univ. País Vasco) «Contribuciones de Joan Coromines a la historia de la lengua vasca» —o texto foi traduzido para galego-português por Jesus Miguel Conde e aparece publicado em Agália, 63/64, p. I5I-158—; às I8:0o h. M. Pueyo (Univ. Lleida) «Fronteres, estats i poblacions en les llengües minoritàries. El cas del català». $\mathrm{Na}$ mesa-redonda celebrada às 19:30 h. «Línguas e Poder» V. Pitarch (Institut d'Estudis Catalans) e M. Pueyo (Univ. Lleida).

O dia i6:00, J. R. Solé i Durany (Dep. de Cultura, Generalitat de Catalunya) «El concepte de llengua pròpia en el Dret i en la normalització de l'idioma» e V. Pitarch (Institut d'Estudis Catalans): «Llengües, cultures, ètnies». Às s 8:30 h. M. C. Henríquez (Univ. Vigo) «A língua do Oeste no DCECH, de Coromines-Pascual» — publicada em Solà (1999: 22I-230)—(Agália, 47, p. 37I-383).

\title{
4. O GALEGO-PORTUGUÊS HOJE (1980-2020)
}

4.I O galego no ensino Primário e Secundário tem as mesmas horas de docência que o espanhol (ou castelhano). Em Primária quatro horas, no Ensino Secundário Obrigatório (ESO) três horas; há matérias optativas. Nas provas da «Avaliaçom do Bacharelato para o Acesso à Universidade» (ABAU) parecem apresentar maior dificuldade os exames de galego que os de espanhol (convertidos num comentário 
de texto e várias questons teóricas estudadas em Primária ou ESO). Toda a teoria e prática docente está centrada para dar por habilitados os alunos, nom interessa que os estudantes falem galego, nem pensem ou debatam sobre a língua, a normativa está sacralizada. Vemos certo paralelismo com a máxima jurídica latina Quod non est in actis non est in mundo "O que nom está nos autos nom está no mundo» = «O que nom está na normativa, nom está no galego».

Nas instituiçons e organismos públicos o uso do galego é «rituário», costumam falar em galego nas sessons, mas nom todos [por ex, o Presidente da Câmara Municipal de Ourense nom o usa), há normativizadores profissionais e os representantes públicos nom se esforçam polo uso «mais correto» do idioma [o ideal de "falar como os melhores» está ausente].

4.2 Os meios de comunicaçom usam o espanhol, ocasionalmente pode aparecer algum artigo em galego (nas Normas do ILG-RAG). Tem havido um notável retrocesso: desde 1977 até 1990 (com Carvalho Calero) e poucos anos depois permitiam publicar em galego-português, agora os textos som escassos. O galego está na Rádio e TVG, porém carece de registos cultos (pobreza de léxico...). O modelo de léxico galego oficialista e isolacionista [...] caracteriza-se por marcados défices de funcionalidade, idiomaticidade, coerência, economia comunicativa e vantagem sociolingüística, o que incapacita tal modelo lexical para constituir o galego em verdadeira língua de cultura, ou seja, em veículo expressivo, eficaz e autónomo do castelhano, de uma sociedade culta e moderna (Garrido 20II).

O único jornal em galego é Nós Diário, nascido em novembro de 20I9; o semanário A Nosa Terra e a revista Agália desaparecêrom; sobrevive Grial (admite textos redigidos em português, porém nom aceita textos em galego-português).

4.3 O reintegracionismo, apesar da censura, limitaçons económicas e do silêncio nos meios de comunicaçom, avança. Desde o ano 1985, recrudescêrom as iras do holding para os seguidores do Professor Carvalho Calero: "Carvalho era oficialmente um home maldito. Um proscrito na sua própria terra. Era alvo de todo tipo de ataques, de quem nom perdoava que umha mente especulativa assi estivesse ao serviço da liberdade de Galiza» (Suevos I99I). Há casos de arbitrariedade, censura, condutas inquisitoriais, expedientes, irregularidades, marginalizaçom, vulneraçom de direitos fundamentais, etc. recolhidos na revista Agália; indicamos o número, ano e páginas: 4 (I985: 479); I4 (I988: 234-235), I6 (I988: 480); I7 (I989: 89-92); I8 (I989: 254-258);

Caplletra 71 (Tardor, 2021), p. 57-94 
I9 (I989: 387-393); 21 (I990: 87); 26 (I99I: 260-26I); 30 (I992: 283-29I); 33 (I993: 7475 e 78); 38 (I994: 2I4-2I6); 42 (I995: 232); 43 (I995: 364-365); 54 (I998: 23I-237) e 6I (2000: I23-I24), etc.

Outro exemplo é o acontecido por motivo da nomeaçom de Eugenio Coseriu como «Doutor Honoris Causa» da Universidade de Vigo. O dia 17 de março de 1995 , no paraninfo da Universidade de Vigo, tinha lugar a solene sessom académica, prévios pedido e proposta do departamento de «Filología Española, Teoría de la Literatura, Lingüística General, Traducción e Interpretación y Latín», em que tivemos a honra de exercer como "madrinha»; na "Laudatio in honorem Eugênio Coseriu» redigida pola autora deste artigo, usamos o galego-português. O problema surgiu quando houvo que publicar o texto: a ortografia utilizada era a denominada «histórica» ou «etimológica» e seguia os postulados que, sobre a ortografia do galego, formularam, entre outros, Sarmiento, Joan Coromines, Rodrigues Lapa ou Carvalho Calero. Nom foi publicada pola Universidade de Vigo (apareceu dez anos mais tarde em Martínez del Castillo 2005: II-20).

4.4 No ano 2020, podemos distinguir três coletivos reintegracionistas de certa importância. Todos eles assumírom o "Acordo Ortográfico da Língua Portuguesa», elaborado de 6 a I2 de outubro de I99I, com a presença de todos os países lusófonos e a participaçom de umha delegaçom de observadores da Galiza, reunidos em Lisboa de 8 a 12 de outubro de 1990 (Vid. Boletim da Academia Galega da Lingua Portuguesa, I, p. 213-234):

a) A Associaçom Galega da Lingua (AGAL) preconiza que o galego deve incorporar-se «ao sistema de.que foi protótipo e que hoje tem como arquétipo a norma lisboeta, sem deixar de ser galego, conservando a sua fonética, a sua morfologia e o seu léxico peculiares [...]» (Carvalho I990: 900). Nom obstante, na morfologia nominal recomendava até 2015 formas em -ám, -ao, -om (anciao, camiom, capitám, irmao, leom, etc.), porque na Galiza nom é necessário marcar a nasalizaçom de umha vogal ou ditongo, e o uso das formas do artigo indefinido umha, umhas (e algumba, nengumha...); da preposiçom per e do pronome demonstrativo $o$, sugere as formas polo, pola, polos, polas; prescreve o numeral cardinal dous e o advérbio de negaçom nom. No tocante ao verbo, as divergências respeito do padrom luso-brasileiro som maiores.

b) A Academia Galega da Lingua Portuguesa (AGLP), constitui-se oficicialmente em Santiago de Compostela em 2008. Entre os académicos correspondentes procede mencionar os Professores Evanildo Bechara; João Malaca Casteleiro (1936-2020) e Carlos Reis, reconhecidas figuras no Brasil e Portugal. 
c) A Associaçom de Estudos Galegos (AEG), novo organismo instituído nos inícios de 2016 e integrado, em larga medida, por antigos membros da Comissom Lingüística da AGAL. Nos poucos anos de existência tem publicado cinco livros, entre outros: Comparativa dos Três Padrons: Galego, Luso, Brasileiro (I-V) (2017), Compêndio Atualizado das Normas Ortográficas e Morfológicas do Galego-Português da Galiza (2017) e Prontuário de Apelidos Galegos (2019).

Como síntese das opçons normativas do galego que hoje em dia continuam a conviver e a concorrer, podemos referir-nos a um artigo publicado recentemente no Nós Diario por Carlos Garrido, professor da Universidade de Vigo e Presidente da Comissom Lingüística da AEG, quem, nesta peça, intitulada «Aspetos essenciais do reintegracionismo escamoteados no discurso público» (quinta feira II de junho de 2020), fala, em relaçom à «adjacente variedade lusitana», de umha norma galega secessionista (a da RAG, promovida polo poder político), de um reintegracionismo subordinacionista (o que propugna a adoçom na Galiza da variedade lusitana, sem maior adaptaçom) e de um reintegracionismo coordenacionista (o da Comissom Lingüística da $\mathrm{AEG}$ ), que reconhece a existência de umha variedade galega autónoma, com os seus legítimos particularismos, mas solidária com as variedades lusitana e a brasileira. Nesta linha, Garrido conclui:

A distinçom entre as duas opçons reintegracionistas, ambas legítimas [...], também nom se deve escamotear porque, na Galiza hodierna, elas poderám desfrutar de diferente recetividade social. A esse respeito, quer-nos parecer que, enfim, a opçom preferida por Carvalho Calero, o reintegracionismo coordenacionista, se inserirá com maior facilidade nos esquemas de umha Galiza politicamente independente de Portugal, de marcado particularismo lingüístico e possuidora de umha tradiçom cultural e literária autónoma.

\section{CONCLUSONS}

a) «Atender só a fenómenos lingüísticos particulares que potenciem a excessiva atomizaçom de um idioma, embora seja interessante na linguagem o pólo da variedade [...] pom em grave perigo o pólo da unidade, garante da intercompreensom [...]». Cumpre sublinhar $[\ldots]$ que «os limites e fronteiras políticas, nom se correspondem necessariamente, com os limites e fronteiras lingüisticas» (Henríquez 1990: 753-754).

b) Os debates sobre a «orthographia» costumam ser constantes e frequentes na história das línguas históricas, porque é a que suporta e dá unidade a qualquer língua de cultura.

Caplletra 71 (Tardor, 2021), p. 57-94 
c) Apenas acrescentar que a divisom provincial tivo lugar no ano i833 e que as três grandes línguas românicas da Península Ibérica (galego-português, castelhano e catalám-valenciano-balear) existem desde muitíssimos séculos antes. Nom deixa de ser surrealista que os estudantes de Filologia Românica na Faculdade de Filosofia e Letras da Universidade de Santiago nos cursos académicos 1963-I964, I964-1965 e I965I966, citássemos os dialetos românicos, segundo os postulados de Ramón Menéndez Pidal. Estes princípios da Lingüística Românica eram os que ensinávamos, quando exercíamos como "Profesora Adjunta Provisional de "Gramática histórica de la lengua española”" (curso académico I966-1967) e Professora encarregada de curso com docência em «Gramática histórica de la lengua española» e «Dialectología Hispánica» (curso académico 1967-1968), onde sempre distiguíamos as três franxas na Península Ibérica. Um antigo aluno nosso, décadas mais tarde Professor Catedrático de Filologia Galego-Portuguesa da Universidade de Santiago, assim o constata:

\footnotetext{
Tenho indicado repetidas vezes um interesse preferencial, desde cedo, pola lingüística diacrónica, que nós, enquanto estudantes, tínhamos assimilado a partir de Menéndez Pidal para o espanhol (omnipresente desde o início das aulas, intensas e extensas, da Prof. Henríquez Salido) e, completado depois do meu concreto ponto de vista, com as leituras de Leite de Vasconcelos, ou de Edwin Williams e José Joaquim Nunes, para o caso do galego-português, representantes canónicos da chamada gramática histórica. (Rodríguez 2020: 6I)
}

d) No que diz respeito da «Carta de las lenguas regionales o minoritarias en Galicia», cap. 8, apenas precisar: a CE de 1978 distingue entre «nacionalidades históricas» e «regiones». Lingüistas e sociolingüistas bascos, cataláns, galegos, valencianos e das Illes Balears usamos a denominaçom «línguas minorizadas» (I. Alonso Estravis, G. Bibiloni, J. Corbera, J. A. Cristóvão et al., P. Fernández-Velho, Ma C. Henríquez, J. Inglès, A. Mollà, V. Pitardh, M. Pueyo, F. R. Bornaetxea, X. Vilar Trilho). Assim se pode verificar no livro, editado pola AGAL (1993):

$\mathrm{Na}$ Galiza [...] além de registar-se umha baixíssima lealdade lingüística e existir também umha menor consciência nacional, a normativa fixada pola RAG e o ILG, e imposta por decreto [...] nom foi aceite formalmente nem por todos os escritores, nem por todos os professores, nem por todas as associaçons culturais, nem por todos os intelectuais, nem por amplos sectores do mundo da cultura. (Henríquez I993: IO2)

Sobre a «ortographia» só acrescentar que a Galiza se encontra no que Calvet (1987: 233) denominava a "guerre des écritures", "por existir umha intervençom directa e ofensiva do poder político e o académico que buscam impor, além da morfologia e do léxico, a grafia da língua dominante sobre a língua dominada». 
Maria do Carmo Henríquez Salido

O galego-português, matriz do mundo lingüistico luso-brasileiro

\section{REFERÊNCIAS BIBLIOGRÁFICAS}

Associaçom Galega da Língua (1993) O uso das línguas na perspectiva da Europa Comunitária, Hizkuntzen erabilera Europar batasunari begina, L’ús de les llengües en la perspectiva de l'Europa Comunitària, Henríquez (ed.), Corunha, AGAL.

Azevedo Filho, L. (I993) «O galego entre o português e o castelhano», Actas do III Congresso Internacional da Lingua Galego-portuguesa na Galiza, Corunha, AGAL, p. 79-82.

Boletim da Academia Galega da Lingua Portuguesa, I, p. 212-234.

Calvet, J-L (1987) La guerre des langues et les politiques linguistiques, Paris, Payot.

Carvalho Calero, R. (198i) Problemas da Lingua Galega, Lisboa, Sá da Costa.

- (1983) Da fala e da escrita, Ourense, Galiza editora.

- (I990) «Bilingüismo e reintegracionismo nas cartas cruzadas entre Castelao e SánchezAlbornoz», Actas do II Congresso Internacional da Lingua Galego-Portuguesa na Galiza, Corunha, AGAL, p. 887-900.

Castelao, A. (196i [I ${ }^{\mathrm{a}}$ ed. 1944]) Sempre en Galiza, Buenos Aires, «As Burgas».

Chaves de Melo, G. (I990) "A terceira vertente», Actas do II Congresso Internacional da Lingua Galego-Portuguesa na Galiza, Corunha, AGAL, p. 59-67.

Comissom Lingüística dA AGAL (I989 [I ${ }^{\mathrm{a}}$ ed. I983]) Estudo crítico das "Normas ortográficas e morfológicas do idioma galego» (I.L.G.-R.A.G.) 1982, Corunha, AGAL.

Coromines, J. (1976) «Sobre a unificación ortográfica galego-portuguesa», Grial, 53, p. 277-282.

Coseriu, E. (I990) «El gallego en la historia y en la actualidad», Actas do II Congresso Internacional da Lingua Galego-Portuguesa na Galiza, Corunha, AGAL, p. 793-80o.

- (I993) «Novos rumos da semântica», Actas do III Congresso Internacional da Lingua Galego-Portuguesa na Galiza, Corunha, AGAL, p. 97-Ioo.

Cunha, C. \& L. F. Lindley Cintra (1985) Nova gramática do português contemporâneo, Rio de Janeiro, Nova Fronteira.

ELIA, S. (I986) «O galego-português matriz do mundo lingüístico lusobrasileiro», Actas do I Congresso Internacional da Lingua Galego-Portuguesa na Galiza, Corunha, AGAL, p. I85-196.

Guerra dA CAL, E. (1985) «Antelóquio indispensável» Futuro Imemorial (Manual de velhice para principiantes), Lisboa, Sá da Costa, p. 5-I3.

Henríquez Salido, Ma do C. (1984) «O reintegracionismo cultural e lingüístico galego-português", Colectânea de Estudos em Homenagem a Rodrigues Lapa, Câmara Municipal de Anadia, p. 2I-35.

- (1986) "As gramáticas do galego», Actas do I Congresso Internacional da língua Galego-Portuguesa na Galiza, Corunha, AGAL, p. 443-467.

Caplletra 71 (Tardor, 2021), p. 57-94 
- (1990) «Línguas, territórios e dialectologia», Actas do Terceiro Congresso da Associação Internacional de Lusitanistas, Universidade de Coímbra, p. 743-754.

- (1993) «A língua e a gramática nas Irmandades da Fala: A Nosa Terra (I916-I920)», Actas do III Congresso Internacional da Língua Galego-Portuguesa na Galiza, Corunha, AGAL, p. 443-467.

- (1996) «O "nosso" mestre Joan Coromines, um grande cientista e um grande patriota", Agália, 48, p. 4II-4I6.

- (1999a) "As fontes galego-portuguesas no Diccionario crítico etimológico castellano e hispánico», J. Solà (ed.), L'obra de Joan Coromines: cicle d'estudi i homenatge, Barcelona, Fundació Caixa de Sabadell, p. 22I-230.

— (1999b): «As ideias lingüísticas no Boletim A Nosa Terra (I92I-1925)», M. Fernández, F. García \& N. Vázquez (eds.), Actas del I Congreso Internacional da la Sociedad Española de Historiografía Lingüistica, Madrid, Arco Libros / Centro Ramón Piñeiro, p. 372-386.

- (2005) «Laudatio in honorem Eugênio Coseriu», J. G. Martínez del Castillo (ed.), Eugenio Coseriu in memoriam, Granada, Granada Lingvistica, Serie Collectae, p. II-2O.

- (20I0) «Las ideas lingüísticas en la Gramática de Juan Antonio Saco y Arce», C. Assunção, G. Fernandes \& M. Loureiro (eds.), Ideias Lingü̈sticasna Peninsula Ibérica, Münster, Nodus Publikationen, p. 39I-408.

Pensado, J. L. (1974) «Sobre el origen de la lengua gallega», Opúsculos lingüísticos gallegos del siglo XVIII, Vigo, Galaxia, p. 9-47.

Pintos, J. M. (I853) A gaita gallega tocada polo gaiteiro [...], Pontevedra, Imprenta de José y Primitivo Vilas.

Rodrigues Lapa, M. (1979) Estudos Galego-Portugueses, Lisboa, Sá da Costa.

- (1986) "Álvaro de las Casas e a reintegração lingüística galego-portuguesa", Actas do I Congresso Internacional da Lingua Galego-Portuguesa na Galiza, Corunha, AGAL, p. 265-269.

Rodríguez, J. L. (2020) José Luís Rodríguez, nos trilhos da língua, Santiago de Compostela, Através Editora.

SolÀ, J., ed. (1999) L'obra de Joan Coromines: cicle d'estudi i homenatge, Barcelona, Fundació Caixa de Sabadell.

Suevos, R. L. (199I) «Elógio da razom práctica», A nosa Terra. Ricardo Carvalho Calero. A razón da esperanza, Vigo, Promocións Culturais Galegas, p. 27-30.

Valadares, M. (1970) Elementos de gramática gallega, Vigo, Galaxia.

Viqueira, J. V. (I917) «O galego na escola», A Nosa Terra, 30 de agosto de I9I7. 
Maria do Carmo Henríquez Salido

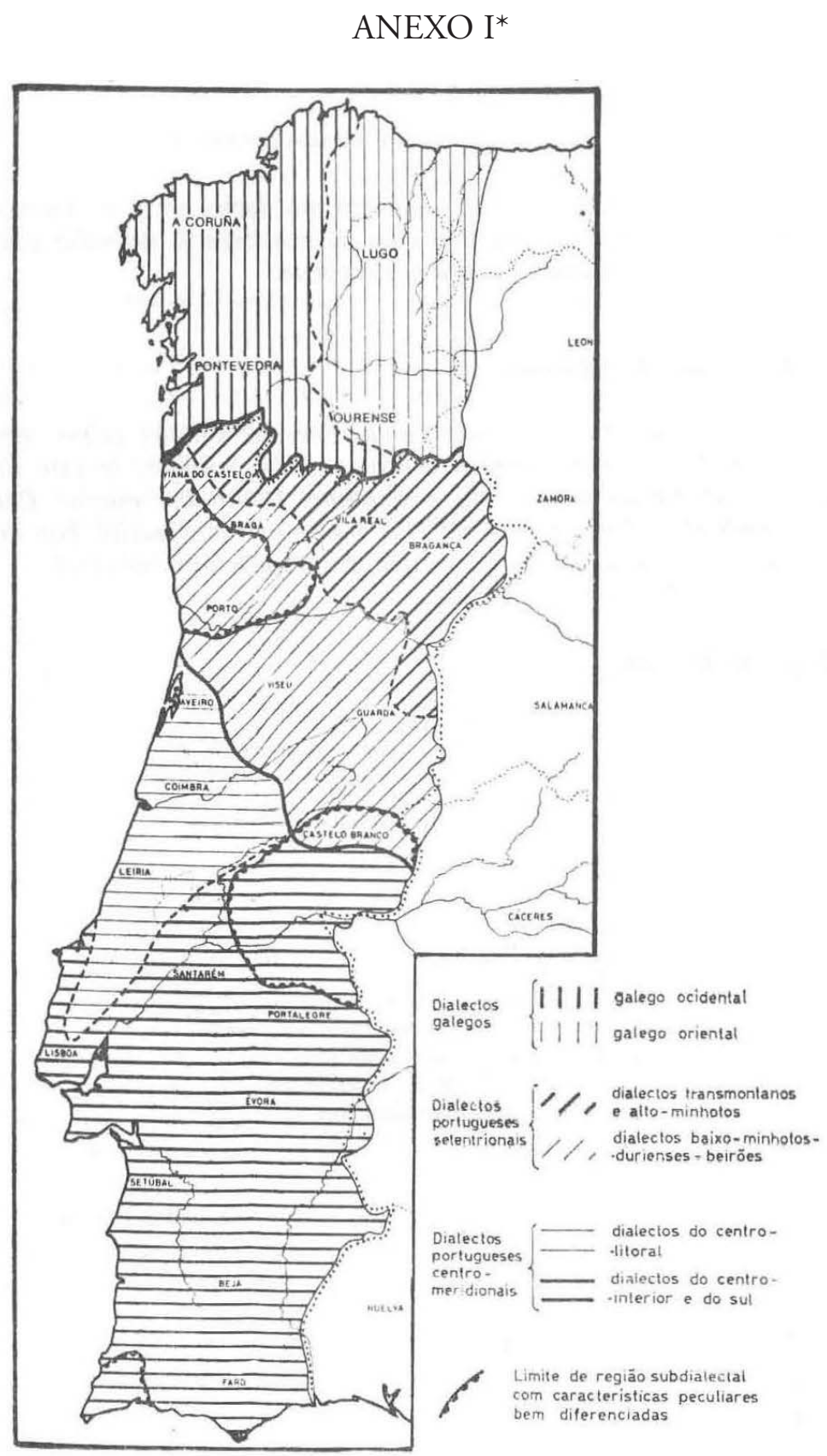

(*) Mapa de Cunha \& Lidley Cintra 1985. 


\section{ANEXO II*}

\section{SOBRE A UNIFICACIÓN ORTOGRÁFICA GALEGO-PORTUGUESA*}

Vaia ante todo a mińa felicitazón ao autor do artigo en prol da unificazón ortográfica galego-portuguesa, publicado no número $5 \mathrm{I}$ de «Grial». ${ }^{1}$ Felicitazón entusiasta: eis a voz da razón, eis o que eu sempre penséi.

Aos meus amigos galegos e portugueses dixen sempre o mesmo, e é precisamente o que se diz nese artigo: o principal adianto a facer na direzón da unificazón lingüística galego-portuguesa é no campo da unidade ortográfica. Dixen sempre isto aos amigos R. Piñeiro, Rodrigues Lapa, Martínez López, Costa Clavell, Xosé L. Pensado, e outros, que poden prestar testemuño. E este adianto é non só eminentemente desexável, mas libre de toda obxeción seria; non só posível mas aínda fácil se existir boa vontade, habilidade e pericia na conduzón do problema.

Nas outras cousas o movimento de freo, de entrave, marcado polo amigo Pińeiro, ${ }^{2}$ paréceme moito razoável, verdadeiramente motivado, profundamente respetável e digno de simpatía.

Quen isto escrebe é un lingüísta estranxeiro, mas sinceramente cheo de boa vontade para todas as línguas hispánicas, fondamente entusiasta e preocupado das cousas da Galiza. Catalán. Autor do Diccionario Crítico Etimológico de la Lengua Castellana e de moitas obras de lingüística romance. Non son un principiante nos traballos de filoloxía galega. No meu ensino na Universidade de Chicago dirixí algúns estudantes meus para os estudos de filoloxía galega (o Prof. Kelvin Parker, autor do Vocabulario clasificado da Crónica Troiana e outros libros máis recentes, foi e é meu alumno); no meu dicionario e nas outras obras miñas há moitas etimoloxías e disquisicións especiáis sobre temas de língua galega.

Non sei se estes tíduos serán suficientes para desculpar que tamén eu me atreva a manifestar o meu parecer sobre a cuestión. Tal vez todo isto non sexa da mińa incumbencia. Tal vez non sería mesmo mui prudente que eu me meta moito nestes asuntos. Por outra parte, os meus deberes están do lado do catalán, a única língua

(*) Texto de Joan Coromines publicado na revista Grial, 53, 1976, p. 277-282.

I. Xosé-Martiño Montero Santalla, Unificación ortográfica galego-portuguesa, en: Grial (Vigo), núm. 5I (xaneiro-marzo 1976), pp. I-I3.

2. Ramón PiñeIro, Carta a don Manuel Rodrigues Lapa, en: Grial (Vigo), núm. 42 (outubro-decembro I973), pp. 389-402. 
miña. $\mathrm{O}$ castelán e o galego-portugués son idiomas irmáns, que teño estudado profundamente; para o galego-portugués a mińa profunda simpatía, para o castelán a desconfianza que merece unha língua que pretende devorar ás outras. Mas a miña obrigación é únicamente para con o meu único idioma: o catalán.

Aliás, o exemplo do catalán e do basco pode e debe guiar ós galegos e portugueses no esforzo de unificazón. Os casteláns traballaron sempre no fomento das pequenas discrepanzas entre o uso literario do catalán de Valencia e de Mallorca e do catalán do Principado; entre os dialectos navarro, guipuzcoano e bizcaíno do basco literario. Foron sempre os partidarlos máis ou menos secretos (ou faceiros) da mingua de vitalidade desas línguas os que pretenderon ser os defensores das singularidades locáis — cando se trataba de Valencia, Mallorca ou Navarra, xamáis cando se trataba do catalán ou basco normáis! É sempre o medo da ameaza castelán o que actuóu de freo ante os movimentos de reacción contra as suicidas tendencias centrífugas no seo das línguas minoritarias.

Son lingüísta, son hispano; se, a tíduo de tal, algún consello meu (cheo de boa vontade!) pode resultar técnicamente útil para os galegos, sentiréime sastisfeito. Se eu fose galego, tería escrito moito sobre todo iso; se fose portugués, non menos, e tería feito algunha cousa, tal vez eficaz, no mesmo sentido. É únicamente o feito de ser estranxeiro — inda que sexa un estranxeiro benévolo e simpatizante- que me privóu de esplicar as mińas ideas. Temo ser mirado con esplicável desconfianza, ser quizáis menos útil que contraproducente.

Aínda con estes temores, permítome seguidamente algúns comentarios detallados das propostas expresadas en dito artigo. Espero que estes comentarios ao mesmo tempo demostrarán ao leitor galego cánto, cuán profundamente, me intereséi sempre por estes asuntos. E concretaréi, referíndome especialmente aos pontos que o autor aborda nas partes 5 -a e 5 -b.

\section{a) PROBLEMAS MERAMENTE GRÁFICOS}

I e 2: $\mathrm{LH}$ e $\mathrm{NH}$

Participo absolutamente na opinión de que se deben adoptar resoltamente as grafías th e $n h$.

O problema de unha, algunha, ningunha é perfeitamente solúvel no senso que o autor recomenda: abandonar o signo $n h$ nestes casos, sen renunciar necesariamente a toda transcripción gráfica desa peculiaridade fonética galega. ¿Por qué non adoptar simplesmente a grafía umha, algumba, ningumba? Non é de certo unha novidade. 
Empregó una amiude o eminente, xamáis abondo ponderado e admirado, P. Martiño Sarmiento; é frecuente nos seus escritos galegos, e no seu Catálogo de Voces Gallegas (publicado por Pensado en 1973). É fácil encontrar ducias de testemuños da grafía umha en documentos locáis galegos dos séculos XIV-XVIII. Por outra parte, con umha casi non se modifica a grafía da OGA; é un cambio levísimo, casi imperceptível. Así respéitase un rasgo propio, popular e distintivo do galego; e porén escrébese nunha forma non chocante para os irmáns portugueses e brasileiros: a diferencia con o port. uma é mínima.

\section{4: Emprego do trazo de unión}

Son bons os argumentos citados para facer aceitável o trazo de unión nos pronomes: economizan acentos, facen máis racional a expresión gráfica da língua. Poderíase engadir que niso coinciden tamén outras línguas romances, como o francés e o catalán: argumento moito secundario, sen dúvida, mas quizáis non enteiramente desprecível.

\section{5: Acentos}

A distinción gráfica entre $e, o$ abertas e fechadas, por meio dos acentos $\left({ }^{\prime} \wedge\right)$, non é somente razoável: é unha esixencia imperativa, elemental, da esencia mesma da língua galega. Absolutamente todos os gramáticos e filólogos galegos coincidiron sempre nese ponto (xa Valladares, Sarmiento, etc.): é unha distinción fonemática básica da língua. Confundir aí é nada menos que atentar ao feito máis básico da fonética galega: é despreciar todas as esencias da língua. O castelán é a única das línguas romances que non posúe esa distinción: a curiosa probeza fónica do cacarexado «idioma riquísimo!»

b) PROBLEMAS DE NATURALEZA GRÁFICO-FONÉTICA

I, 2, e 3: G, J, X; C, Ç, Z; SS

Estes pontos son evidentemente máis delicados, como o autor víu moito ben. Paréceme prudente a suxestión feita no ponto 3: «non sería escesivamente grave que de momento se deixase neste ponto unha certa liberdade no uso». Excelente atitude, que se podería facer extensiva aínda aos pontos i e 2 desta mesma sección. Sen transixir permanentemente, quede claro. 


\section{4: Grupo QU}

Seguramente é nos pontos 4 e 5 desta sección onde unhas certas reservas galegas á completa identidade son máis conselláveis.

O ponto 4, porén, non é grave. Non atenta seriamente á unidade o feito de que en unhas rexións do idioma se escreban cando, catro, canto, calhar, etc., as palavras que nas rexións maioritarias lemos como quando, quatro, quanto, qualhar.

Porén sería útil dicer: quarenta mellor que coarenta ou corenta; quantía, non contía. No fin de contas — asemade - quarenta soa casi igual que coarenta; quantía cuasi como contía. Recomendar tambén quasi, non cuase ou case (que deben ser consideradas como pronuncias populares, aceptáveis únicamente no uso folklórico, rústico ou poético da língua). Entón escreber tambén a qual (non a cual), quarzo, qualidade, quaternario, frequente, etc.

Nunha palavra: manter a unidade con o portugués, aínda neste ponto, nos casos en que o galego vacila entre $c a$ - e cua- ou co-. Defender somente as voces fundamentáis: cando, catro, canto e casos tais.

\section{5: Nasalidade}

É éste o ponto en que sería máis difícil chegar á identidade completa con o portugués. Eu inclinaríame a dar algún consello restrictivo da unificazón neste único ponto. Temo que, se se recomenda escreber coração, razão, questão, e mesmo lá, campá, regióes, carbóes, pódese chocar con unha resistencia invencível. Tal vez sexa contraproducente a intransixencia aí. Con todo, guárdome de dar consellos resoltos e detallados neste ponto: só unha asamblea de estudiosos e literatos galegos, depóis de un estudo frío, ponderado, prudente, poderá dar con unha solución viável.

Algunha suxerencia provisional, moito reservada, podería eu facer. ¿Por qué non limitarse a recomendar a adopción de $-m$ final no lugar de $-n$ ? Isto é máis fácil, máis leve, pode triunfar máis lisamente. A diferencia entre razón e razom, fin e fim, can e cam, en e em, bon e bom, etc., é máis leve, encontraría moita menos resistencia; e as formas en $-m$ terían xa un aspecto aceptável para os portugueses e brasileiros: en fin de contas os portugueses mesmos escreveron -om, -am, etc., até o século pasado (ou até o XVIII en todo o caso). Para o pobo galego é indiferente $-m$ ou $-n$ : ao fin o que pronuncia non é nin unha dental nasal, nin unha labial: é velar, soa no fundo da boca.

En consonancia con isto, ao menos provisionalmente escreber estaciom ou estaçom, naciom, regiom (non estação, nação, etc.).

Caplletra 71 (Tardor, 2021), p. 57-94 
c) OUTRAS CUESTIÓNS

I: I en vez de $\mathrm{Y}$

Deberíase decidir unha unificazón imediata no senso de $i$, xamáis $y$ ! É un adianto considerável no terreno da unificazón e con pouca resistencia popular.

\section{2: Duplicados; epéntesis}

Paréceme tamén importante que se adopten medidas unificadoras en outros asuntos non propia e estrictamente ortográficos. Por exemplo: tal vez se deba renunciar a certos duplicados coexistentes en galego, que dan a impresión dunha linguaxe vacilante, dialectal: de unha fala, máis que de unha língua. Por exemplo, o emprego de $i$ diante de vogal, en lugar da conxunción $e$.

Xa que logo, deberáse escreber sempre $e$ ele, non $i$ ele, aínda admitindo que a pronuncia y-ele é lexítima, mas non literaria; non ensinável, únicamente tolerável, sobretudo en estudos locáis, folklóricos, ou en usos populares, ou líricos, da língua.

Da mesma maneira deberíase renunciar á apéntesis de vogal en casos como adimirar, adimitir e análogos, formas populares, toleráveis quizá, mas non recomendáveis. Igualmente en formas como a $i$-agua, a $i$-alma, etc.

\section{3: Os cultismos}

En especial considero esencial chegar a unha pronta unificazón con o uso portugués no caso dos vocábulos cultos. É éste un ponto de importancia capital, para conferir ao galego ese sentimento de dignidade, esa conciencia de idioma culto, de rango civil, civilizado, supra-comarcal, en que tan acertadamente se insiste como esencial para a defensa da língua na conciencia ciudadán dos galegos.

Por exemplo, nos grupos de consoantes dos cultismos. Felizmente o portugués neste ponto non é tan cultista como o castelán ou o francés. (O catalán é diferente tambén: nós non temos dificultades no cultismo consonántico; este problema non existíu para nós). A conduta do portugués é de unha transacción moderada entre as dúas atitudes estremas. O meu consello resolto neste ponto é que os galegos se ateñan decididamente ás solucións portuguesas.

Por exemplo: efeito, defeito sí, máis efectivo, afectuoso, projecto, dialecto, trajecto, carácter, texto, textil. Formas como dialeuto, caráiter, e aínda efeitivo, terán sempre un resaibo algo bárbaro para moitos. Poderemos aínda pronunciar proxeito, produto, máis o rango de idioma románico esixe ortografiar projecto, producto. Deberáse escrever non eiscelente, mas excelente, exército, exercicio; non eisame, mas exame, examinar. 
Pronúnciese, se se quer, eisame: isto é secundario, perfectamente tolerável; mas escreber urbanamente!

Aconsellaría simplesmente adoptar en todos os detalles as grafías portuguesas: estender, mas extensión, extenso; existir (xamáis eisistir); substancia (non importa o pronunciarse sustancia: nengunha obxeción); setembro, estranho, escuro (non os ultracultismos do castelán septiembre, extraño, obscuro!); excremento, executar, exagerar (non esaxerar); nobre sí, mas ignóbil ou polo menos inóvel; digno, ben que a pronuncia sexa, naturalmente, dino; excursión, expoer, eximio, etcétera.

En particular recomendaría eu que no caso do sufixo -ável, -ivel, -vel, adopten sempre a forma portuguesa en - $e l$, pois que esa mesma forma existe en galego nun bon número de casos. Lémbrome que o máis grande prosista que o galego moderno teve fasta agora - quero dicer naturalmente Castelao, un dos meus ídolos literarios!sempre escrebe as formas en -vel (ele tal vez con - $b$ - gráfico nalgún caso, excepción que se podería eliminar): favorável, non favorabre nin favorávele; posivel, non posibre, etc.

(NOTA: Podería ter escrito con ortografía unificada ou en portugués; non o fiz, para demostrar a miña atitude de absoluto respeito con as decisións que corresponden únicamente aos galegos. Podería tamén ter escrito en castelán, menos cansada para min, e evitaría os numerosos erros que sei que cometín con o galego. Máis o meu desexo é mostrar que a miña simpatía é para o galego, nunca para o castelán. O leitor galego saberá disculpar eses erros.)

JOAN COROMines

Barcelona 
ANEXO III*

\section{EL GALLEGO EN LA HISTORIA Y EN LA ACTUALIDAD}

I. Como el principal problema actual del gallego es un problema práctico y de política cultural —el de un "gallego unificado" y de la función de éste en la Región Galicia-, se piensa comúnmente que hablar de la posición lingüística del gallego y de sus problemas implica que se deba "tomar partido" y significa "tomar partido". Ahora bien, es cierto que el de la constitución de una lengua común es también, y en primer lugar, un problema político y que la lengua de una comunidad, como primer rasgo individualizador de ésta, puede ser objeto de pasión política. Por ello, es justo que los gallegos que hablan o quieren hablar gallego (así como los que no quieren hacerlo) tomen partido; más aún: deben tomar partido, pues lo que está en juego es su individualidad histórica y cultural. Pero no cabe que tome partido el lingüista que examina objetivamente los problemas del gallego, incluso los problemas políticos (si es gallego, el lingüista tomará posición como gallego, no como lingüista «imparcial», aunque empleará, por supuesto, también argumentos lingüísticos como instrumentos de lucha política). Y, sobre todo, no cabe esperar del lingüista que confunda intencionalmente los problemas. Porque, en efecto, se trata de tres problemas diferentes.

a) el problema de la posición lingüística objetiva del gallego entre los idiomas peninsulares, problema de lingüistica, en particular; de lingüística histórica;

b) el problema de la función que ha de tener el gallego en Galicia, entre los gallego-hablantes o simplemente en esa región: problema de política idiomática;

c) el problema de cómo ha de ser el gallego, de la forma que conviene que asuma, sea cual sea la función que tenga: problema de planificación lingüistica.

Aquí - sin querer intervenir en el debate político, que concierne sólo a los gallegos y, en cierto sentido, a los españoles y a los portugueses - nos ocuparemos sólo del primer problema, o sea, del problema histórico de la posición del gallego entre los idiomas de la Península Ibérica.

2. En lo que concierne a este problema, los romanistas e hispanistas están en general de acuerdo en que el gallego es una forma particular del conjunto dialectal gallego-portugués, en cuanto opuesto al conjunto dialectal español (no "castellano», sino: astur-leonés, castellano, en sus muchas formas, y navarro-aragonés) y al conjunto catalán (o catalán-valenciano), y, precisamente, en relación al español, una forma más cercana (y no sólo geográficamente) al astur-leonés y, más estrictamente,

$\left(^{*}\right)$ Comunicaçom de Eugenio Coseriu publicada nas Actas do II Congresso Internacional da Lingua Galego-Portuguesa na Galiza, 1990, p. 793-800. 
Maria do Carmo Henríquez Salido

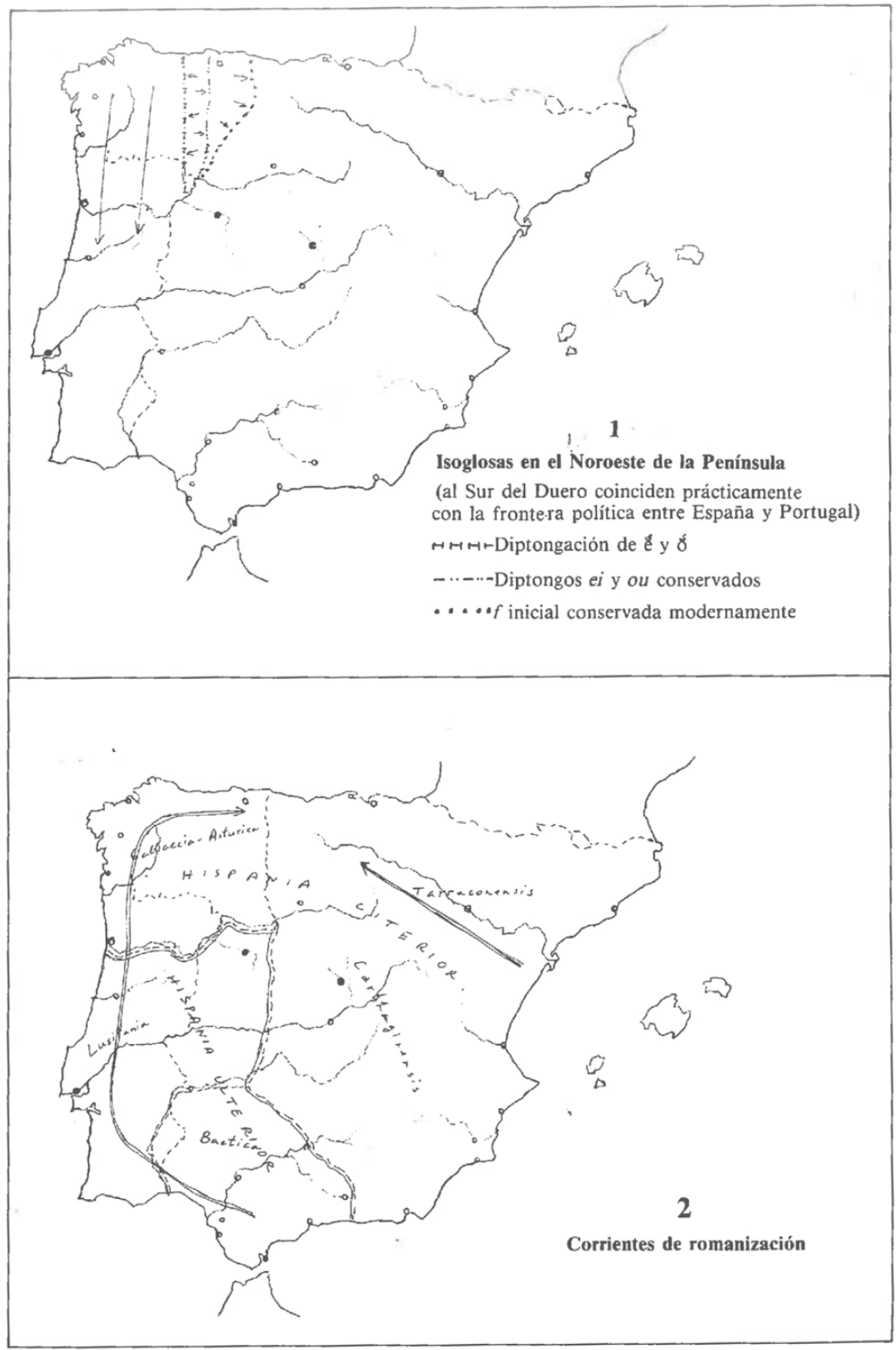


al asturiano, que a los restantes dialectos españoles (véase, por ejemplo, el mapa «La Romania actual» en: W. von Wartburg, La fragmentación lingüistica de la Romania, o el de las principales isoglosas hispánicas [«España dialectal»], en la Gramática histórica de R. Menéndez Pidal, ( $c f$. Mapa I). pero, con esto, el acuerdo casi se acaba. Ello, en muchos casos - y no sólo fuera de la Península Ibérica一, por desconocimiento de la posición efectiva del gallego; pero en más casos quizá, sobre todo en estos años, por actitudes que se refieren a nuestros problemas segundo y tercero. Esto último, claro está, muy en particular entre los "galleguistas» y en Galicia, donde los antagonismos se han venido polarizando, como es sabido, en torno a dos actitudes básicas, la de los «autonomistas» y la de los «lusitanistas». Los autonomistas, también llamados a veces, por sus adversarios, «castellanizantes», al abogar —en lo concerniente al tercer problema - por la autonomía del gallego, oponen el gallego al portugués literario y común y tienden a exagerar las diferencias con respecto a estas formas del portugués; así, destacan que fenómenos "gallegos» se extienden, a nivel dialectal, hasta Asturias y León, pero no que, en este mismo nivel, se extiendan también a todo el Norte de Portugal. Los «lusitanistas» señalan esto último, pero, al querer acercar el gallego cada vez más al portugués, le atribuyen también formas que en gallego - o, por lo menos, en el gallego actual - ya no tienen existencia real. Por lo mismo, los «autonomistas» atienden sobre todo al gallego actual y a sus tradiciones más recientes; los «lusitanistas», en cambio, atienden sobre todo al gallego histórico, más cercano al portugués. Frente a esto, sería ingenuo querer adoptar una actitud de compromiso y decir que, como con frecuencia ocurre, la razón está en el medio. Convendrá más bien tratar de establecer históricamente la naturaleza de la relación entre el gallego y el portugués y preguntarse a partir de qué época y en qué sentido se puede hablar de gallego, de gallego-portugués y de un gallego opuesto al portugués.

3.I. Con respecto a la época romana más antigua, desde el desembarco de los Escipiones en Ampurias, en 2 I8 a. C., y hasta la reforma administrativa de Caracalla, en 216 d. C., no sólo no cabe hablar de una unidad galaica, sino que no hay siquiera señales del delinearse de una unidad precursora de ésta en el latín de Hispania. Lo que se está delineando en esta época son dos unidades que no coinciden con ninguna de las lenguas actuales de la Península Ibérica, a saber, una unidad correspondiente a la corriente de romanización que parte de la Tarraconense en dirección noroeste y una unidad correspondiente a la corriente de romanización que, partiendo de la Bética, se dirige hacia la costa atlántica y, siguiendo a lo largo de esta costa, llega hasta las actuales Galicia y Asturias; es decir que, si esto hubiese seguido en el mismo sentido, hoy tendríamos, probablemente, en Hispania dos lenguas románicas: una para gran parte de la Hispania Citerior, otra para la Hispania Ulterior y la parte occidental de la Citerior (cf. Mapa 2). 
Maria do Carmo Henríquez Salido

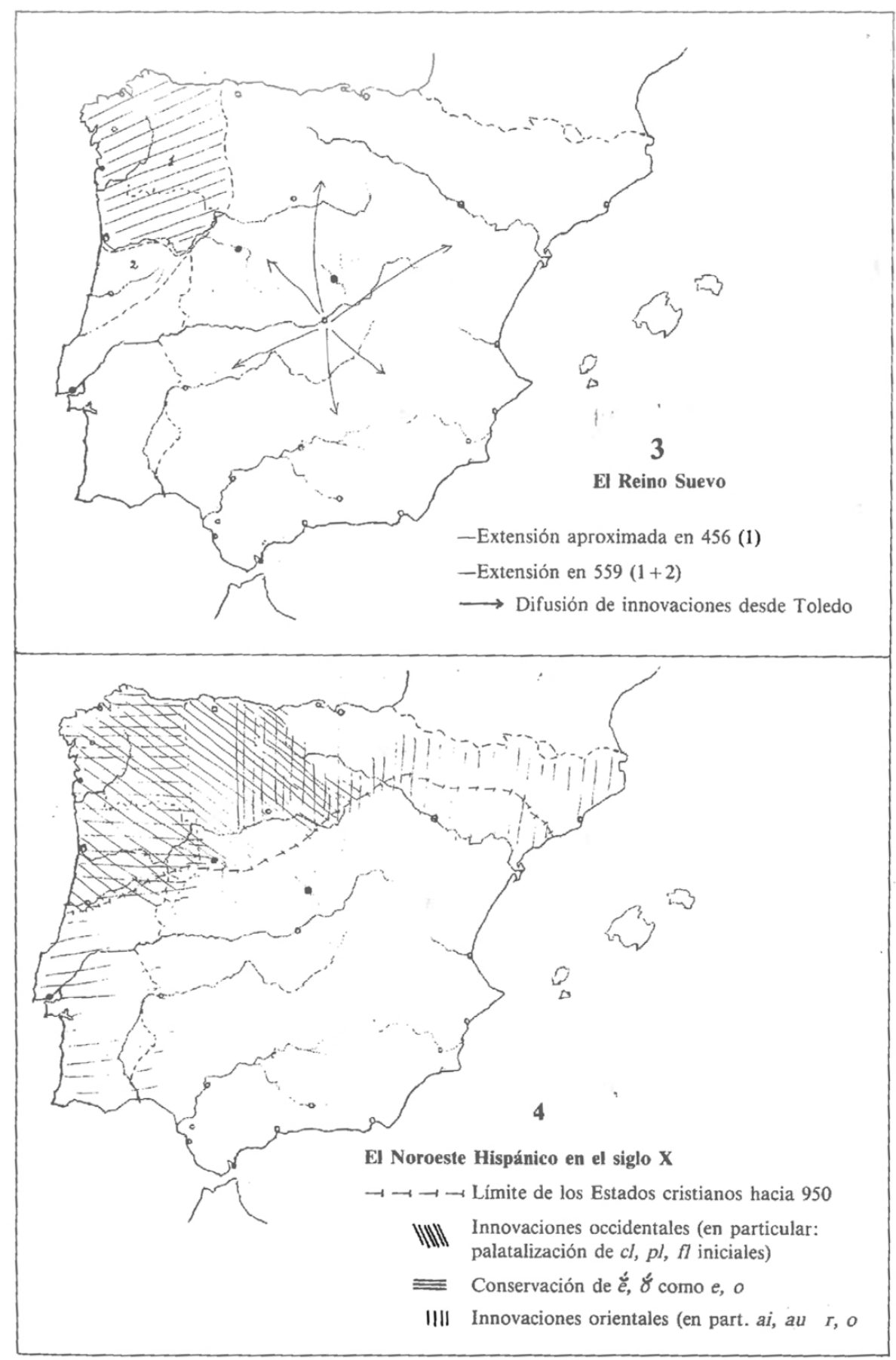


Hacia una unidad, si no propiamente galaica, por lo menos con el centro en Galicia, se tiende, de algún modo, con la creación de Gallaecia Asturica en el marco de la reforma de Caracalla y, más aún, con el reino suevo en Galicia, en el Siglo v (cf. Mapa 3). Pero la unificación de Hispania bajo los visigodos interrumpe el desarrollo en este sentido y lo que ahora se perfila como posible es más bien una sola lengua románica para toda la Península, con el foco de irradiación de las innovaciones en el centro de la misma. Poco después, la invasión árabe interrumpe también este desarrollo, mucho antes de que las innovaciones partidas desde el centro pudiesen difundirse por toda la Península y antes de que una eventual norma toledana pudiese imponerse, también como norma de conservación, a los centros innovadores de Gallaecia y de la Tarraconense. De suerte que, ahora sí, puede hablarse ya del perfilarse de una unidad gallega (o, quizás, galaico-asturiana), sobre todo con la creación del reino de Asturias, que muy pronto engloba a Galicia.

De aquí en adelante, la historia política y, por ende, lingüística de la Península está determinada, bien se sabe, por la Reconquista. Lo que en lo lingüístico se está perfilando como posibilidad son una serie de lenguas en el Norte (una para cada uno de los reinos que van surgiendo) y otra lengua más en la Hispania árabe (siempre que no la reemplacen las lenguas que, con la Reconquista y la repoblación, se difunden desde el Norte). Y una de estas lenguas que se están delineando en el Norte podría ya llamarse "gallego», por tener su centro precisamente en Galicia (cf. Mapa 4). Por lo que puede deducirse de la fonética histórica, es un dialecto ante todo conservador, en particular, en comparación con el castellano, pero en parte también frente al catalán. Así, frente a cast. harina, mujer, ojo, enero, pez, lomo, pie, puerta, dinero, oro, ocho (es decir, a las formas que el castellano tenía en aquel entonces y que éstas continúan), presenta las formas más antiguas; farin'a, mul'er, ol'o, zaneiro, peise, lombo, pe, porta, din'eiro, ouro, oito. Pero — y es lo que más importa— presenta también una serie de innovaciones que lo caracterizan; así, la reducción de $m$ 'n a $m$ (hominem > omne > ome), la caída de $n$ y $l$ intervocálicas (luna > lua, palu > pau) y la transformación de los grupos $p l, f l, c l$ iniciales en $\check{c}$ (por ej., čuvia, «lluvia»; čama, «llama»).

3.2. No es difícil advertir que todos estos fenómenos, tanto los de conservación como los de innovación, caracterizan también al portugués, que no existe todavía como tal. Podríamos, por consiguiente, hablar de una lengua "gallego-portuguesa», y no sin razón geográfica, ya que el dialecto en cuestión abarca también las tierras entre el Miño y el Duero, o sea, lo que más tarde sería el Condado de Portugal. Por otra parte, sin embargo, las conservaciones que oponen esta lengua al castellano, al catalán o a ambos dialectos son propias también del asturiano, por lo menos, del 
asturiano occidental, y — lo que, otra vez, es más importante - también algunas de sus innovaciones se extienden a ese mismo asturiano occidental. De acuerdo con el criterio adoptado con respecto a las lenguas que «se están delineando», deberíamos, por lo tanto, decir que - como en la época anterior - se está perfilando una lengua "galaico-asturiana» con el centro en Galicia; tanto más, en cuanto una unidad política «Portugal» todavía no existe.

3.3. Ahora bien, precisamente en este momento, en que la lengua «galaicoasturiana» no es todavía tal y en que la unidad gallego-portuguesa es un hecho lingüístico real, pero es todavía simplemente unidad gallega, sobreviene la ruptura entre el gallego de la nueva Galicia y aquella parte del mismo gallego que se convertiría en "portugués»: Alfonso VI crea en I093, dentro de Galicia, el Condado de Portugal, que en II28 logrará su independencia y en II30 se transformará en reino. Y, con ello, empieza también la diferenciación entre el gallego "común» que se continúa en la Galicia reducida y el «neo-gallego» que pronto será "portugués». Frente a la orientación político-lingüística anterior hacia el Este y hacia el Sur, la nueva unidad política, y con ella su lengua, se orientan —y con más decisión- sólo hacia el Sur. La capital del Estado se traslada de Guimarães a Braga, de Braga a Coímbra, después a Santarém y a mediados del Siglo xiII a Lisboa, la gran ciudad mozárabe reconquistada ya en II47. Y la lengua gallega se transforma en contacto con el mozárabe de estas mismas regiones y se torna, también "oficialmente», lengua portuguesa. El viejo gallego, en cambio, queda aislado en el Norte y queda también prácticamente detenido en su desarrollo. De todos modos, las innovaciones más recientes que se difunden en una u otra dirección pueden ahora detenerse en la frontera política del Miño, que llega por tanto a ser también frontera lingüística. Además, después de un breve florecimiento literario, el gallego se continúa sólo en el nivel dialectal, con la carencia de norma común que esto implica, mientras que el portugués, asumiendo como propia también la tradición del gallego de la poesía "galaico-portuguesa», se desarrolla a la vez como lengua común y literaria.

3.4. No hay duda, pues, de que el gallego es la base del portugués. Éste no es sino "gallego modificado por los mozárabes», o, como quieren algunos, «mozárabe modificado por los gallegos», aunque esto último sea menos aceptable, dada la gran unidad entre el Norte de Portugal y Galicia y dado que todo lo esencial, en la fonética y en la gramática, había ocurrido ya antes de esta época en la base del portugués. Lo cierto nos parece sólo que la gran ciudad mozárabe de Lisboa, conquistada en época tan temprana, debe de haber ejercido sobre el portugués naciente una influencia mucho

Caplletra 71 (Tardor, 2021), p. 57-94 
más importante que la que pudieron ejercer sobre el castellano las grandes ciudades del Guadalquivir conquistadas un siglo más tarde, cuando el castellano tenía ya más de un siglo y medio de vida toledana y en el Sur el mozárabe se había reducido a una existencia muy precaria.

4.I. Más bien cabe preguntarse si las innovaciones ulteriores, por ambas partes, son tantas y tales que puedan justificar que se hable de una separación efectiva entre los dos idiomas. Esto no parece ser así, sobre todo si se compara el gallego (y todo el gallego, no sólo un gallego unificado) con el portugués popular y dialectal, no con el portugués «normativo».

Entre las innovaciones portuguesas en la fonética se citan:

-la transformación de $\check{c}$ en $\breve{s}$ (así, čover > šover, escrito chover) y

—la de $\dot{s}, \dot{z}$ en $s, z$ (en palabras como saber, passar, casa),

— así como hechos más tardíos, casi sólo de distribución fonemática o de realización fónica y que no afectan al sistema funcional: el cambio de $o$ final en $u$, la velarización de $l$, la realización de $s$ implosiva como $s$, la reducción de las vocales átonas, la reducción del diptongo ou a $o$.

Y del lado del gallego se señalan:

-el ensordecimiento de las sibilantes sonoras $(\check{z}, \dot{z}, z>\check{s}, \dot{s}, s)$,

—la pérdida de las vocales nasales (irmáns, irmaos frente a irmãos; razón frente a razão),

-la confusión de $b$ y $v$

- la reducción de qua a ca (cando, catro).

4.2. Ahora bien, de estos fenómenos, si nos limitamos a los principales, sólo el ensordecimiento de las sibilantes es exclusivo del gallego: su límite hacia el Sur coincide con la frontera política. La pérdida de la nasalidad caracteriza, sin duda, al gallego, pero se encuentra esporádicamente también en Portugal (y, al revés, la nasalidad se presenta, aunque en medida mínima, también en Galicia). En otros casos, hay continuidad entre Galicia y todo el Norte de Portugal, a veces casi hasta el Tajo; $y$, ello, tanto en el caso de las conservaciones (correspondientes a innovaciones "portuguesas") como en el caso de las innovaciones gallegas (correspondientes a conservaciones "portuguesas». Así, śse mantiene también en el Norte de Portugal, en una parte de la antigua Galicia meridional (y, precisamente, al lado de $z$, puesto que no ha habido desonorización); $c$ se mantiene en todo el Norte (Viana do Castelo, Bragança, Porto, Viseu) y se encuentra incluso en el Brasil; el diptongo ou llega casi hasta Lisboa; y de las innovaciones, la confusión de $b$ y $v$ llega hasta Coímbra. En varios casos, como 
Maria do Carmo Henríquez Salido

O galego-português, matriz do mundo lingüistico luso-brasileiro

el de la reducción de las vocales átonas o el de la pronunciación de la $s$ implosiva, la fonética gallego-portuguesa más antigua se conserva también en el Brasil, de suerte que, si se separase el portugués del gallego, habría que separarlo también del brasileño.

4.3. Tampoco son muy importantes las divergencias en la gramática. Entre las innovaciones portuguesas se señalan:

-los plurales del tipo animais (frente a varias formas, entre ellas también animais, en gallego) y cães (gall. cans),

- el cambio de la desinencia - des en -is (cantades > cantais),

—la acentuación esdrújula de las dos primeras personas del plural del imperfecto (cantávamos frente a cantabamos),

-la confluencia de te y tibi en te (frente a gall. te, če),

- la supresión de las contracciones en casos como tódolos > todos os, comelo pão > comer o páo.

$\mathrm{Y}$ entre las gallegas:

-la desinencia -o de la $3^{\text {a }}$ persona de los pretéritos fuertes (dišo, frente a port. disse),

—la $\mathrm{I}^{\mathrm{a}}$ pers. sing. en $-n$ en los pretéritos de la $2^{\mathrm{a}} \mathrm{y} 3^{\mathrm{a}}$ conjugación (por ej. comín frente a comì),

- ti por $t u$,

- formas como tivečes, tivéčedes en las $2^{\text {as }}$ personas del pretérito,

-la no-inclusión del objeto pronominal entre la forma de infinitivo y el auxiliar en el futuro y el condicional (direi-l'e frente a dir-lhe-ei).

Se observará que en las innovaciones portuguesas se trata en varios casos sólo de regularización y fijación de formas y que algunas no han llegado a generalizarse (así, los tipos arcaicos tódolos, comé-lo pão se encuentran en la lengua popular de gran parte de Portugal), y varias de las innovaciones gallegas no son generales en gallego (así ti por tu y las formas tivečes, tivécedes). Otras innovaciones gallegas se encuentran también en el portugués dialectal o en el Brasil (así direi-lhe); y en el caso del acento "latino" de gall. cantabamos, no puede excluirse que se trate de un hecho secundario: en efecto, el gallego acentúa erámos, erádes, pero fišéramos, fišérades.

Incluso la variación diatópica del gallego coincide a veces con la del portugués. Así, el «seseo» dialectal en el Norte de Portugal, es propio también del gallego occidental; la $i$ «antihiática» (en casos como a minha-i-alma) tiene amplia difusión regional en ambos idiomas; y también en gallego las perífrasis del tipo de port. estou a fazer alternan regionalmente con las del tipo de port. estou fazendo.

Caplletra 71 (Tardor, 2021), p. 57-94 
4.4. En el léxico, por cierto, las diferencias son a veces sensibles, pero, en rigor, no son mayores que entre el portugués de Portugal y el portugués popular del Brasil. Lo que distingue la relación entre el portugués y el gallego de la relación entre el portugués y el brasileño es que el gallego no tiene un léxico común unificado, que en muchos casos el gallego carece de formas propias por carecer de una tradición en el nivel «culto» y que entre el portugués de Portugal y el brasileño siempre ha habido y sigue habiendo intercomunicación, lo que no se ha dado y no se da entre el portugués y el gallego.

5.I. Con todo, o sea, a pesar de que durante siglos no ha habido contactos efectivos, el gallego y el portugués siguen perteneciendo al mismo conjunto, al mismo continuum lingüístico. La separación puede, sin duda, establecerse en el plano de la lengua común (que para el gallego, en parte, se está todavía elaborando), pero no a nivel popular y dialectal, de suerte que, para la lingüística histórica, sigue teniendo plena vigencia la denominación compuesta «gallego-portugués» creada, según parece, por lingüistas alemanes.

5.2. Claro que esto no significa que el gallego sea "portugués»; significa más bien lo contrario: es el portugués el que es «gallego». Históricamente, el portugués es el gallego de la Reconquista y es hasta hoy, en todas sus formas, la continuación de ese gallego. Esto vale también para el portugués literario y común en su relación con el gallego literario medieval, pues la tradición de este gallego ha sido adoptada y continuada por la lengua literaria portuguesa. Se trata, por tanto, del caso, bastante raro en la historia de las lenguas, de una lengua que, precisamente en la forma que se difunde y se constituye en lengua común y gran lengua de cultura, se llama con otro nombre: ya no gallego, sino portugués. Es un caso análogo al del holandés literario y común, que, en sus orígenes, es una forma del bajo alemán; sólo que la base común del gallego y del portugués era un idioma mucho más unitario que el conjunto de dialectos bajo-alemanes y que, debido también a diferencias cuantitativas, nadie considera el bajo alemán como «forma del holandés».

\author{
Prof. Dr. Eugénio Coseriu \\ Universität Tübingen \\ Romanisches Seminar \\ Wilhelmstrasse, 50 \\ D. 5400 - TÜBINGEN, I (ALEMANHA)
}

